I+Diseño

Revista Internacional de Investigación, Innovación y Desarrollo en Diseño / ISSN 1889-433X

\title{
Pep Carrió: correspondencia y deriva
}

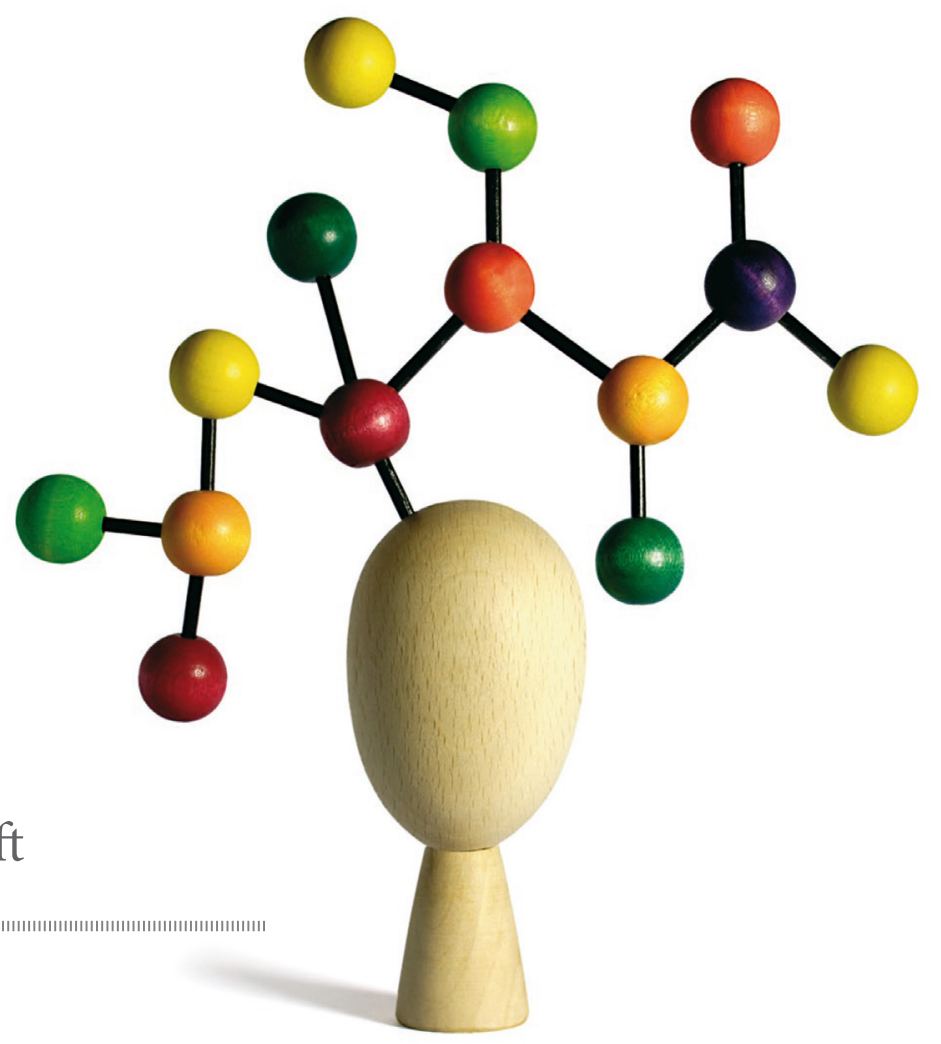

\author{
Grassa Toro \\ https://grassatoro.com/
}

Quien haga una búsqueda en internet tecleando «Pep Carrió» encontrará sin mucha dificultad dos webs que se ocupan de su obra: https://www.pepcarrio.com y https://cargocollective.com/pepcarriolab.

Quien decida conocerlo en su espacio de trabajo acudirá a su estudio de diseño gráfico en un ático en el centro de Madrid o a su taller de artista en un semisótano del barrio de la Concepción de Madrid.

Quien investigue su biografía descubrirá que nació en Palma, en una isla, y vive en Madrid, capital del estado.

Podríamos fantasear con la existencia de dos profesionales homónimos, o que uno solo llevara doble vida; quedaría en pura fantasía: es el mismo Pep Carrió con una sola vida. ¿Y una sola obra?

Si entendemos por obra, el conjunto de su producción es obvio que solo hay una. Si entendemos por obra cada creación de «alguna importancia» tenemos que hablar de miles. Al aproximarnos al recuento, que no está hecho, surge la primera evidencia: la producción de Pep Carrió es descomunal.
Artículo original / Original Article

Correspondencia / Correspondence grassatoro@gmail.com

Financiación / Fundings Sin financiación

Recibido / Received: 13/11/2021

Aceptado / Accepted: 13/11/2021

Publicado / Published: 17/12/2021

Cómo citar este trabajo. How to cite this paper.

Grassa, C. (2021). Pep Carrió: correspondencia y deriva. i+Diseño. Revista Internacional de Innovación, Investigación y Desarrollo en Diseño, 16. DOI: $10.24310 /$

Idiseno.2021.v16i.13827 

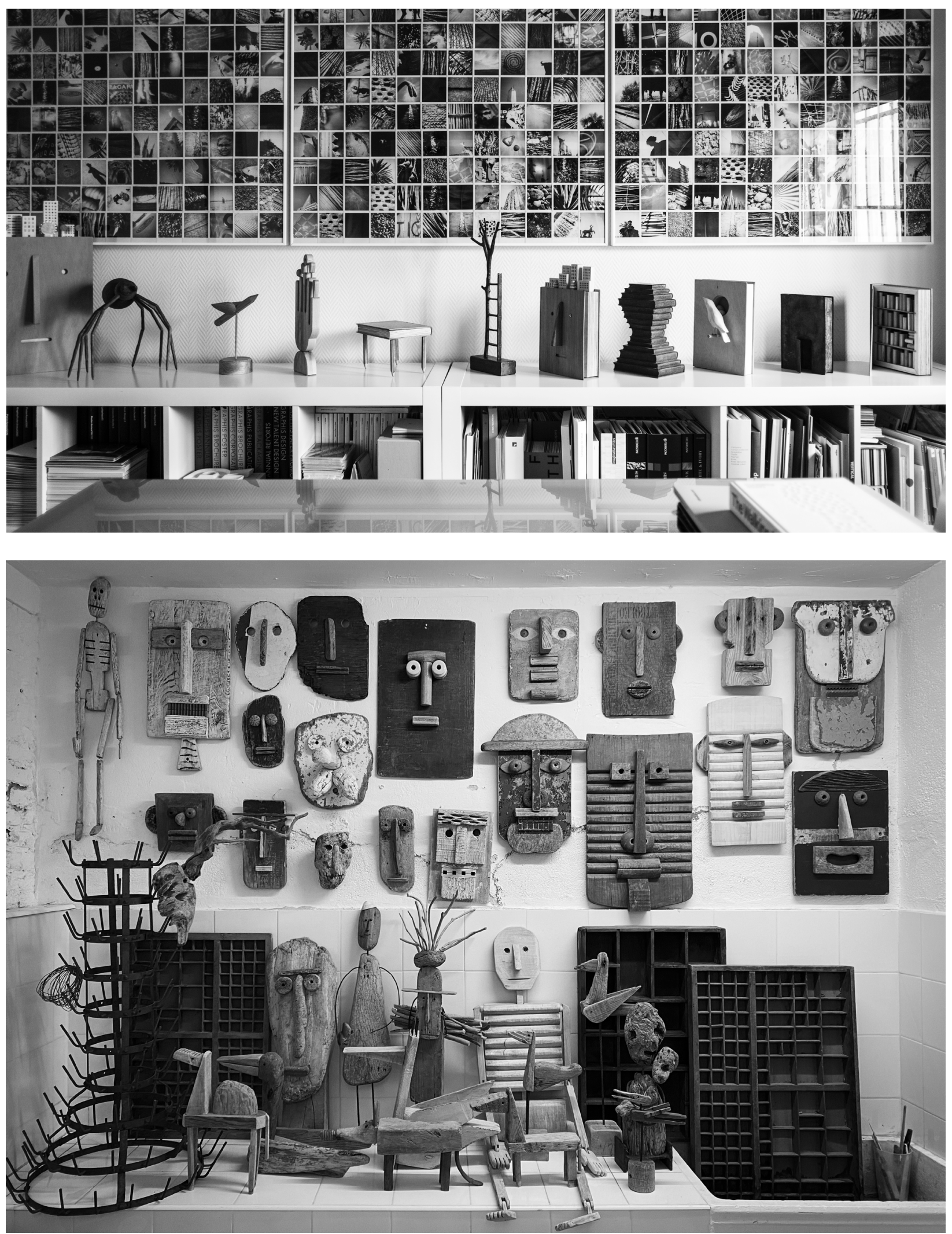
La segunda evidencia es la variedad dentro de su obra, también poco común, variedad de soportes, técnicas, materiales, herramientas, lenguajes, procedimientos retóricos y poéticas. Carrió puede pintar con rotuladores una piedra recogida en la orilla del mar; fotografiarla variando las proporciones, hasta que parezca una isla; utilizarla en su estado virgen como pieza escultórica; manipular digitalmente la imagen de la piedra para ilustrar la cubierta de un libro; dibujarla a línea sobre un folio blanco mientras habla por teléfono.

Ante semejante corpus, y si nuestro interés es, más allá de la contemplación, identificar algunos procesos de creación que han generado tan vasta producción, renunciamos a abarcar la totalidad de la obra y vamos a proceder, con un cierto talente detectivesco, al estudio de algunos casos que entendemos son paradigmáticos. Utilizaremos el método clásico de seguir las pistas, intentaremos establecer genealogías que nos descubran los múltiples nexos de conexión y correspondencias (quizás sea esta una de las palabras clave de nuestro método inquisitivo) que subyacen a los procesos de creación y que abocan a algo que, por analogía, podríamos llamar la «Constelación Carrió». Avanzaremos en deriva, sin ninguna connotación negativa, todo lo contrario: entendiendo el hecho de derivar como profundamente vital y generador. Corresponder y derivar. Investiguemos.

\section{Caso 1. Las tablas de lavar}

Antiguamente, cuando se lavaba a mano, se utilizaban tablas de lavar, eran un pedazo de madera rectangular estriado que permitía frotar la colada en la orilla del río o sobre las losas del lavadero público; un objeto de uso que ha dejado de usarse y que Pep Carrió encontraría en algún momento en alguno de los rastros que visita a lo largo del mundo. Carrió, en su condición de artista, clavó sobre la tabla varios cientos de puntas de metal que pueden percibirse como una imagen figurativa semejante a unos labios femeninos (mayores) o como una forma geométrica y, por tanto, abstracta. La pieza podría ser una ajustada respuesta a Cadeau, de Man Ray (1921, editioned replica 1972), readymade que consiste en una plancha sobre cuya base el artista coloca
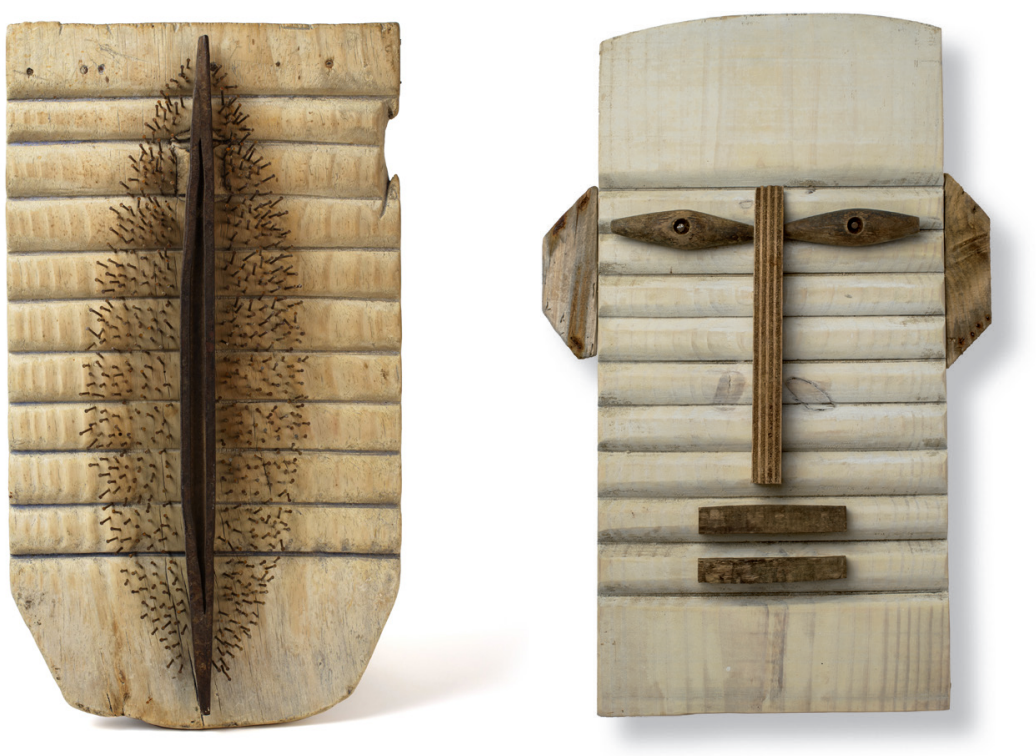

Figura 1.

En la página anterior arriba Estudio de diseño Pep Carrió. Madrid. Abajo Taller Pep Carrió. Madrid.

Figura 2.

A la izquierda El origen del mundo. Exposición Ars erótica. Galería Dionis Bennassar. Madrid. 2013. A la derecha Fray Vicente Valverde, 2012. 
Figura 3.

Conquistadores en el nuevo mundo. Grassa Toro / Pep Carrió. Tragaluz, 2013.

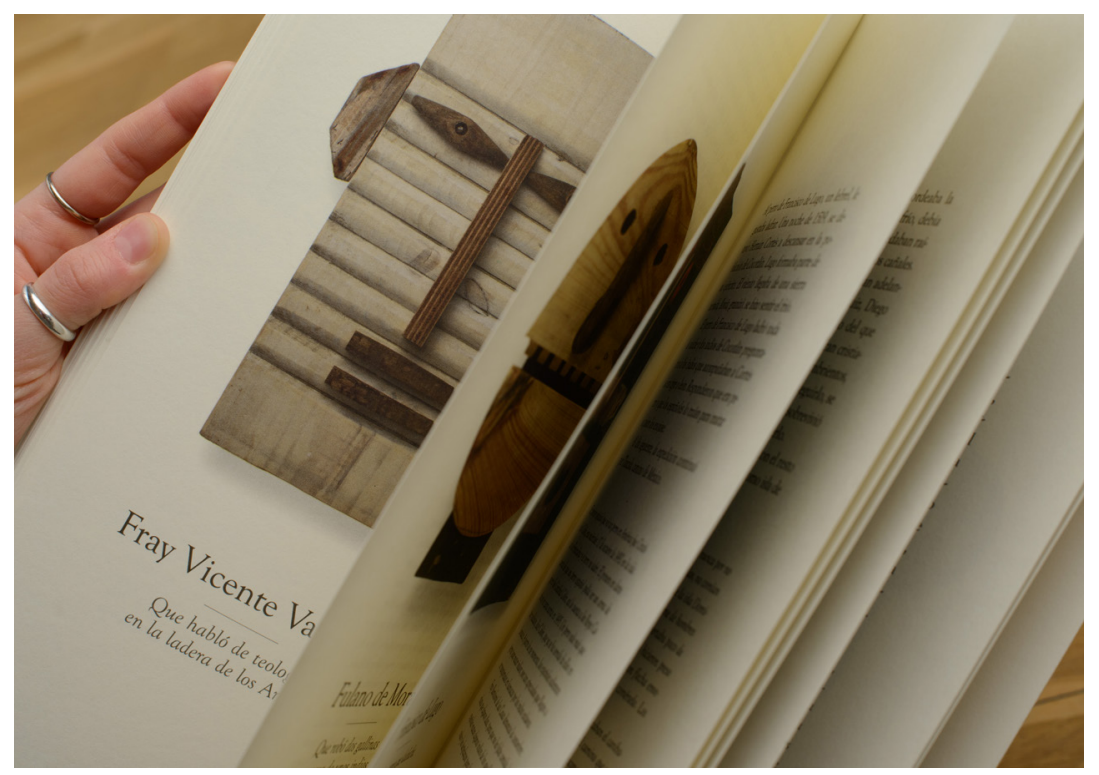

catorce clavos con la punta hacia fuera. Podría ser una respuesta, pero es probable que no lo sea porque entre los intereses de Pep Carrió, y son muchos, no destaca el de la creación meta artística.

El caso (el $n^{\circ} 1$ ) es que esta pieza de la tabla de lavar, expuesta en su momento en galería de arte, adquirida como pieza única según las reglas del mercado y perteneciente a una colección particular, quedó definitivamente clasificada como obra de arte.

Encontramos una segunda tabla de lavar a la que Carrió ha añadido unos cuantos restos de madera que algún día fueron piezas de otro objeto de uso cotidiano (quizás armario); y ordenando los elementos ha conseguido una representación imaginaria del rostro de Fray Vicente Valverde ("Que habló de teología en la ladera de los Andes»). Las características de esta pieza original son semejantes materialmente a las de la primera tabla de lavar, su función es bien distinta: ilustra un texto y, convenientemente fotografiada, aparece impresa en un libro (Conquistadores en el Nuevo Mundo, Medellín, Tragaluz, 2013), que permitirá multiplicar por miles su reproducción, lo que propiciará una difusión de la misma en nada comparable a la de la primera tabla de lavar.

Utilizar un objeto recreado como imagen de ilustración en un libro infantil, alejándose de la prevalencia del dibujo en este tipo de publicaciones, sigue siendo excepcional y este uso conserva la capacidad de sorpresa con la que un día no muy lejano nos sorprendió Juul (Salamanca, Lóguez, 1996), ilustrado por Koen Vanmechelen, artista conceptual belga (y no ilustrador).

La tercera tabla de lavar (en realidad la cuarta, porque en Conquistadores en el Nuevo Mundo el retrato de Juan Velázquez también estaba hecho de la misma materia), apareció en 2015, en una exposición en La Factoría de Papel, Madrid, titulada Espejo del alma; fue una doble aparición, por un lado era una pieza única colgada de una pared, por otro lado era una imagen reproducida digitalmente junto a otras imágenes, en tirada de 100 ejemplares firmada por el autor y numerada, el conjunto guardado en una caja. 


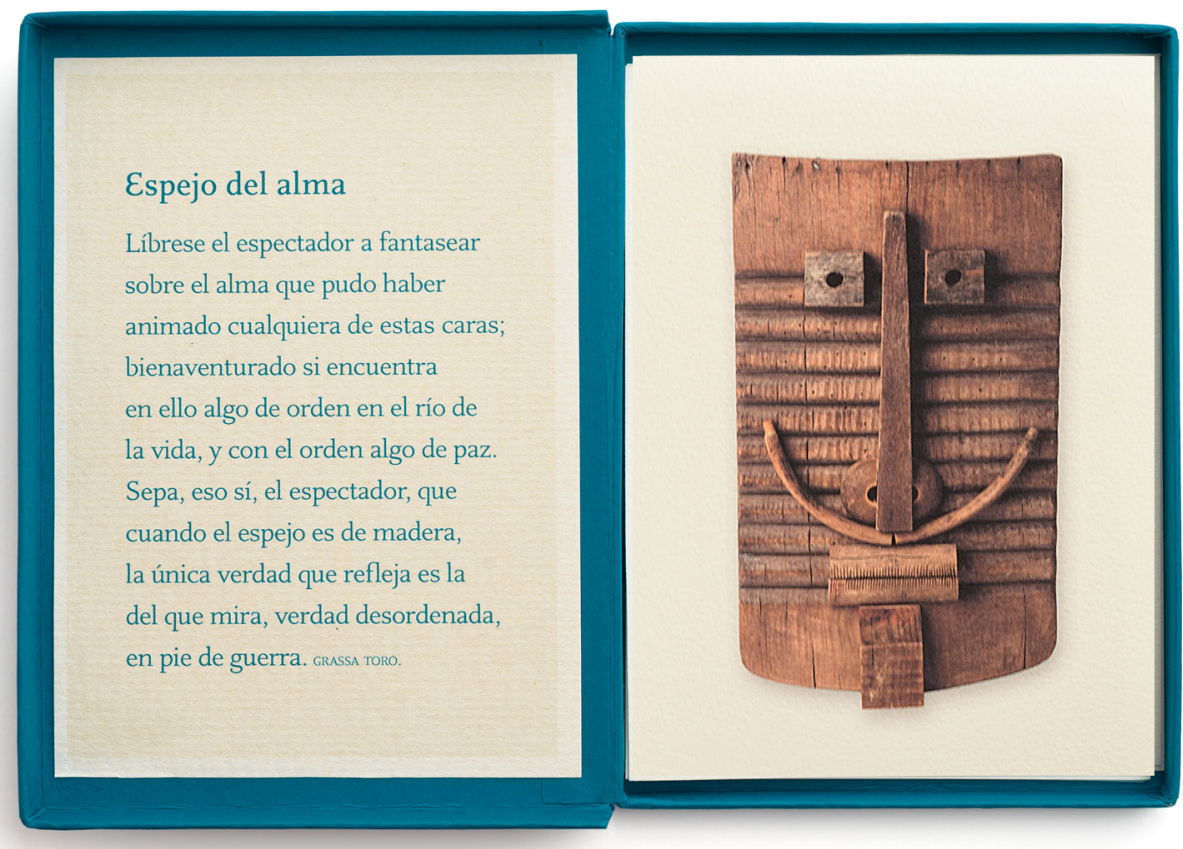

Figura 4.

Arriba Espejo del Alma. Caja con estampas digitales. 2015.

\section{Figura 5.}

Abajo Exposición Espejo del Alma. La factoría de Papel. Madrid, 2015.

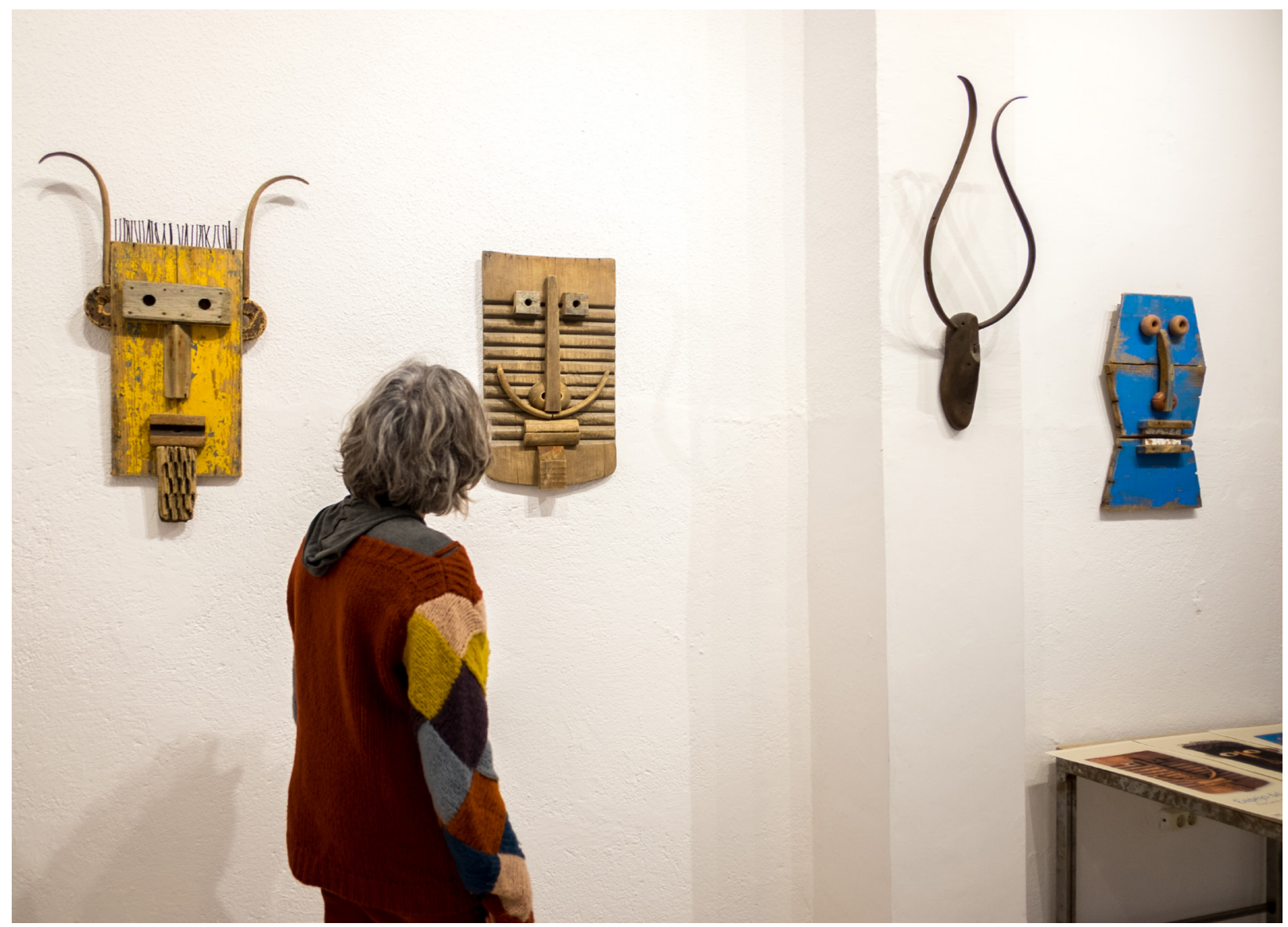



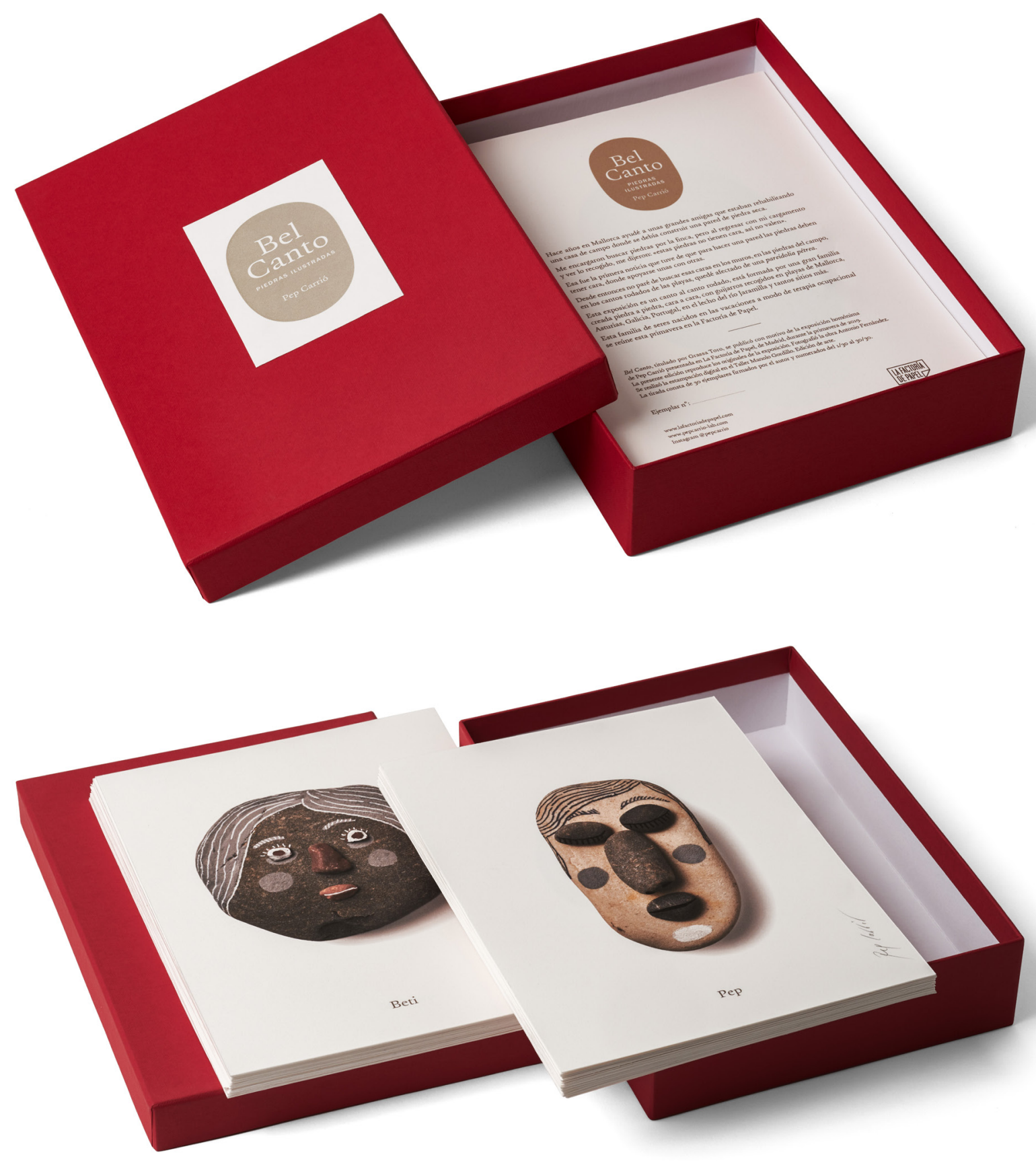

Figura 6.

Bel Canto. Caja con estampas

digitales. Factoría de Papel, 2019. 
El uso de cajas como contenedores de obra única u obra seriada, más o menos numerada, atraviesa la historia del arte del siglo XX: Marcel Duchamp, Robert Filliou, Jean Michel Alberola o ANCA (Associació Nous Comportaments Artistics) son jalones en este recorrido. Estas cajas cumplen una doble función, la referida como contenedores, función útil, y una segunda que se superpone, la de formar parte de la propia obra de arte. Pep Carrió volverá a utilizarlas en otros proyectos: Bel canto (La Factoría de Papel, Madrid, 2019) y Systema Naturae (La Factoría de Papel, Madrid, 2018).

Antes, mucho antes de que aparezcan estas cajas, exactamente desde el siglo pasado, Pep Carrió ha llenado otras cajas de variopintos objetos: piedras, conchas, ojos de plástico, fotografías viejas, recortes de mapas antiguos, collages creados por él, y las ha enviado a sus destinatarios dentro de un sobre, sin que podamos considerarlas arte postal, pues no hay intervención alguna sobre el propio soporte de envío, lo que lejos de decepcionarnos por no poder establecer correspondencia con otra de las manifestaciones diferenciadoras del arte del siglo XX, nos anima a celebrar la variedad de posibilidades de difusión de la obra artística. Sobre estas cajas, piezas únicas diseminadas por el mundo en colecciones privadas, no hay inventario documental, lo que también, lejos de decepcionarnos, es un acicate para futuras investigaciones.
Estas cajas cumplen una doble función, la referida como contenedores, función útil, y una segunda que se superpone, la de formar parte de la propia obra de arte.
Figura 7.

Systema Naturae. Caja con serigrafías. Factoría de Papel, 2018.
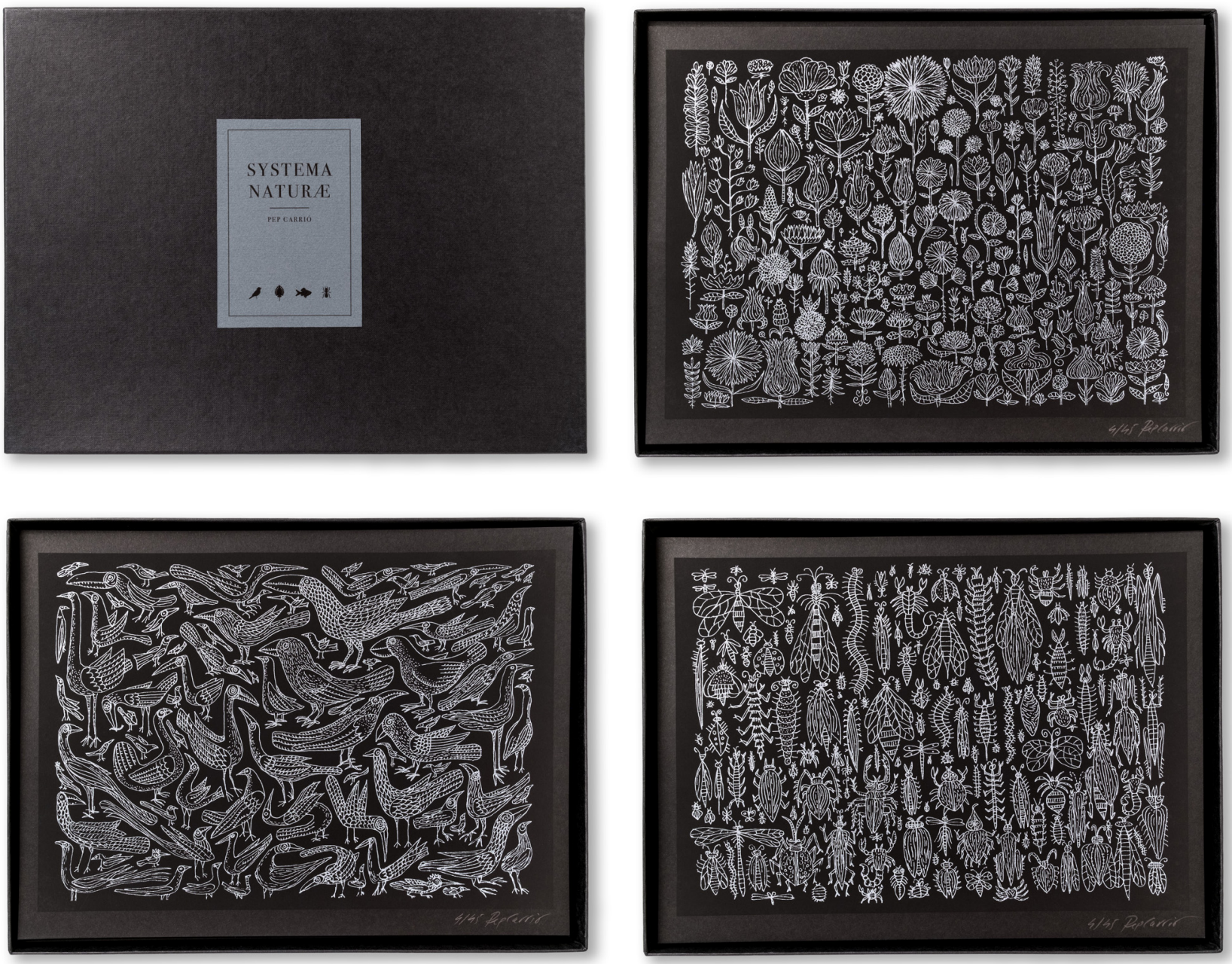
Hemos empezado hablando de antiguas tablas de lavar y hemos terminado hablando de Ulises Carrión, aunque no lo hayamos nombrado hasta ahora. Esto tiene la investigación detectivesca, una pista lleva a la otra y así.

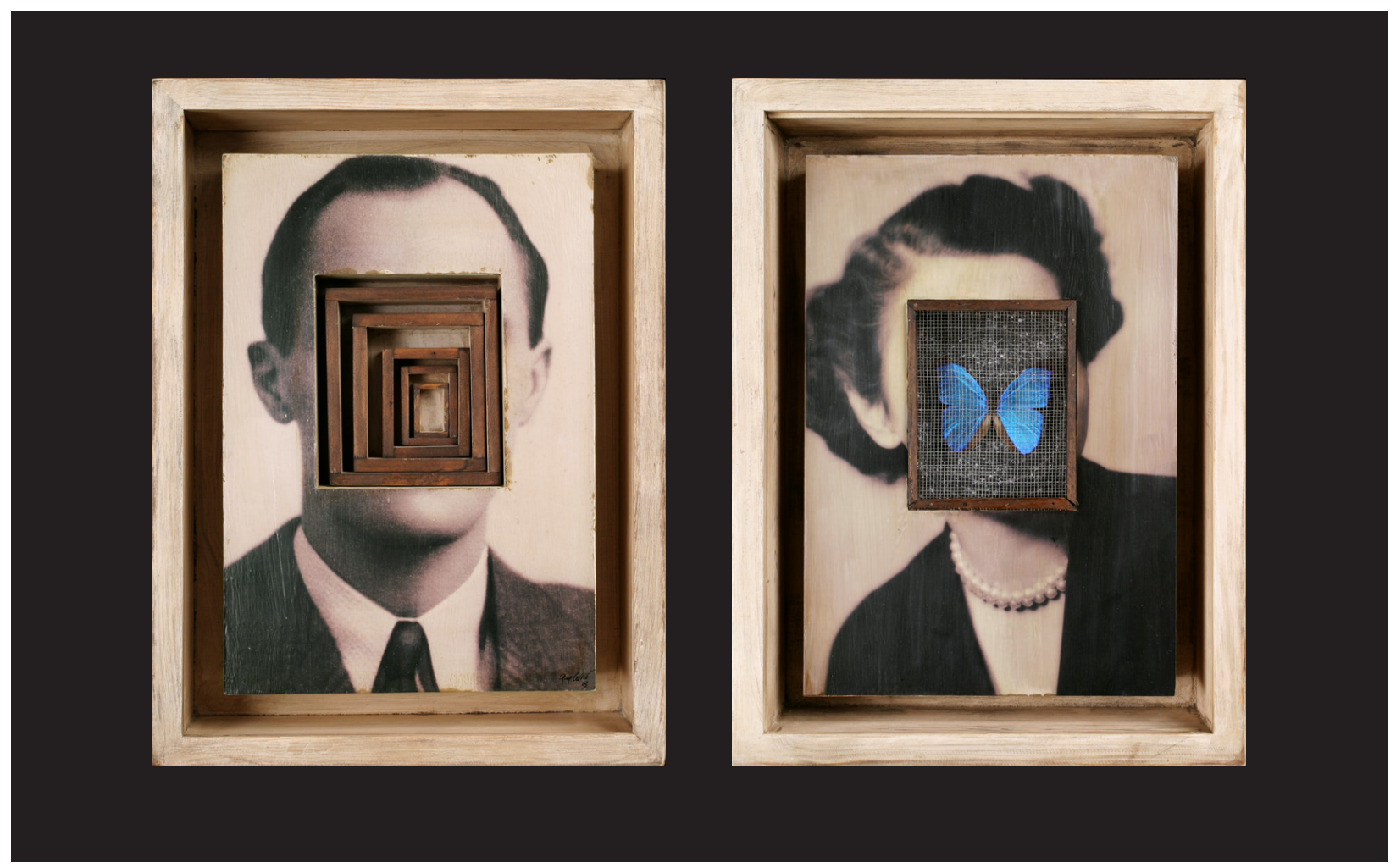

Figura 8.

A la derecha Encajado. Caja, fotografía y objetos, 2004. A la izquierda Mariposa. Caja, fotografía y objetos, 2004.

\section{Caso $N^{\circ}$ 2. Las fotografías encontradas}

Pep Carrió encuentra fotografías en contenedores de derribo, aceras de ciudades (sobre las aceras también encuentra naipes), mercados de pulgas; las recoge, las guarda, las acumula. Son fotografías de seres humanos, quienes han posado, quienes han disparado, y quienes las han perdido o las han abandonado son seres humanos.

En su primera exposición individual en condición de artista, Tránsitos, (UNED, Barbastro, 1999) ya aparecen algunas de ellas. Volverán a aparecer (sí, son apariciones) en Pasajeros (Galería Serrahima, Barcelona, 2000) y serán la base, literalmente, de But my face I don't mind for I am behind it (Fundación Guifré, Barcelona, 2004).

En Pasajeros, la obra de arte se construye mediante procedimientos de acumulación de ensamblaje, la contigüidad de decenas de fotografías establece una sintaxis más o menos consciente que, a su vez, invita al relato; retórica que coincide con la de Boltansky y que, como poética, y pese a las apariencias, no evoca la memoria, sino todo lo contrario: el olvido en el que han caído todas esas imágenes, todas esas vidas abandonadas.

Alinear a Pep Carrió con Boltansky sirve, entre otras cosas, para recordar que el último tercio del siglo XX puso en primer plano el uso del documento (una fotografía familiar es un documento) y su transformación como objeto artístico. 

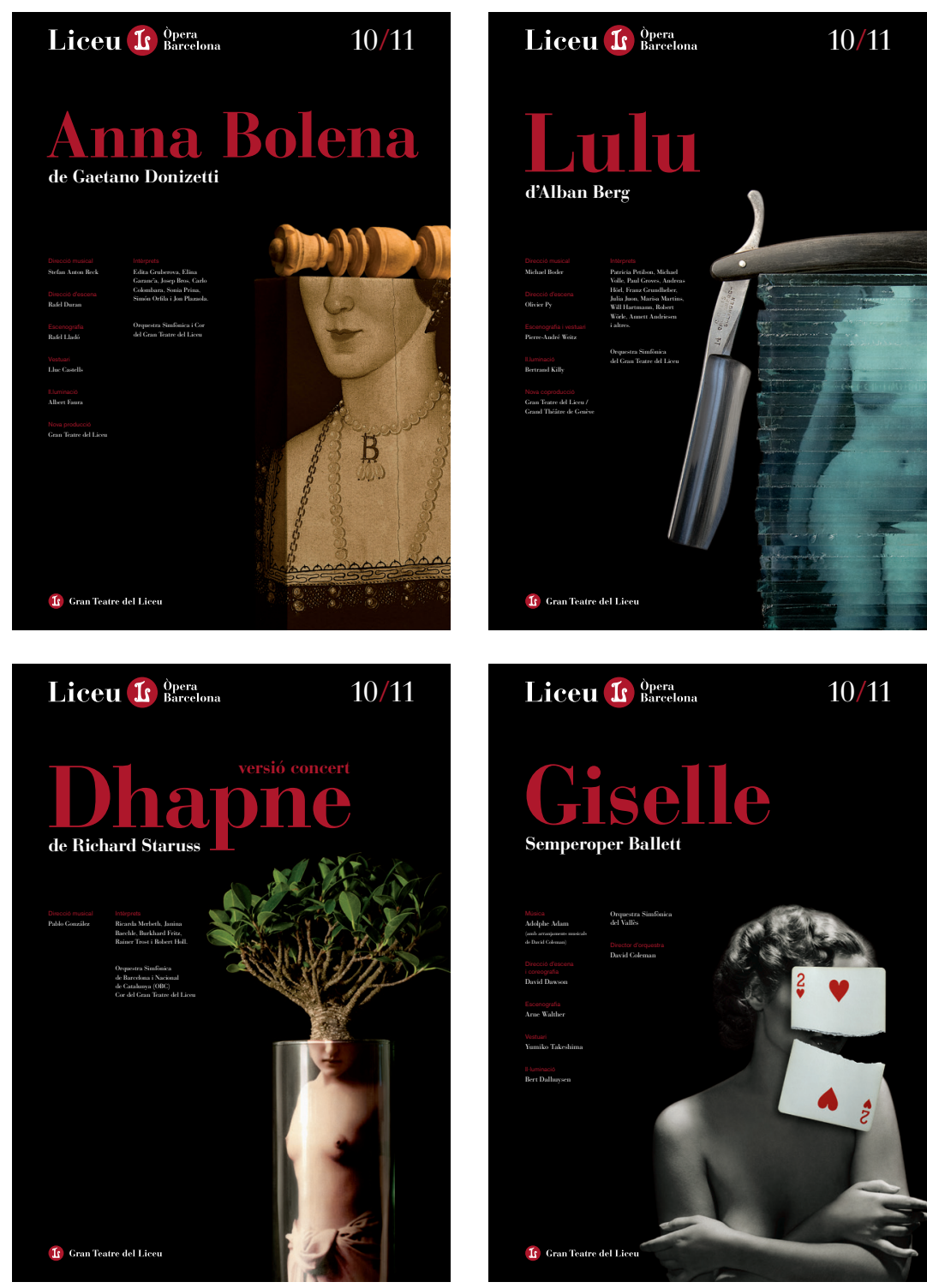

Distinto, muy distinto, será el uso que haga de la fotografía encontrada Pep Carrió en But my face I don't mind for I am behind it. En este caso, el procedimiento elegido es el collage, atendiendo a una de sus definiciones canónicas: utilización de objetos y/o imágenes ya existentes integrándolos en una creación nueva por superposición (y no por yuxtaposición, como sucedía en el caso de Pasajeros). En But my face I don't mind for I am behind it, sobre una fotografía encontrada se superpone otra imagen o un objeto generalmente encontrado, apenas un binomio cuyo resultado ya no apela a memorias ni olvidos documentales y entra de lleno en el terreno de lo irracional. Max Ernst (Escrituras. Barcelona, Polígrafa, 1982) supo definirlo, él mismo se pregunta y se responde: ¿¿CUÁL ES LA MÁS NOBLE CONQUISTA DEL COLLAGE? Es lo irracional. Es la irrupción magistral de lo irracional en todos los dominios del arte, de la poesía, de la ciencia, en la moda, en la vida privada de los individuos, en la vida pública de los pueblos. Quien dice collage dice lo irracional».

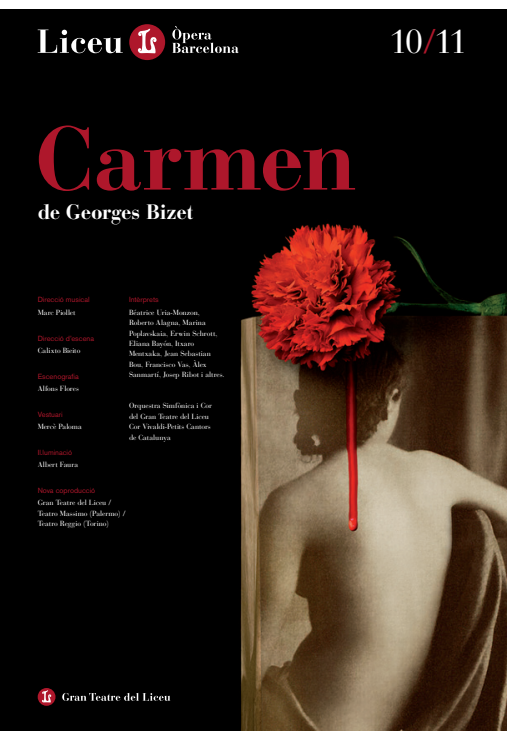

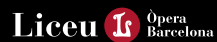 \\ $10 / 11$}

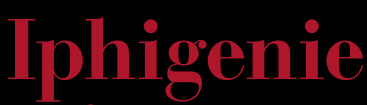

\section{auf Tauris}

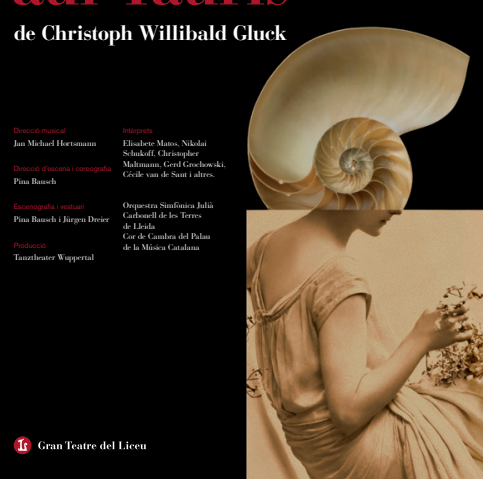

Figura 9.

Carteles temporada de Ópera 20102011. Gran Teatro del Liceu. 
La imagen irracional es una de las constantes en la obra artística de Pep Carrió, y el collage, con una amplia variedad de materiales, una de sus formas preferidas de expresión.

Seis años después de esta exposición, Carrió diseñará los carteles para la temporada 2010/2011 del Teatro de Ópera Liceu de Barcelona, las imágenes que ilustrarán los carteles y los programas de mano serán collages compuestos por una fotografía de base y un objeto superpuesto. Decimos bien «ilustrarán» porque en este caso ya no se trata de piezas de arte, sino de imágenes que acompañan un texto informativo, el de cada representación en el Liceu: título, dirección, reparto, etc. Imágenes que insertadas en un cartel tienen principalmente una función comunicativa, al servicio de un mensaje definido de antemano y sirviendo de portavoz a un tercero: el Liceu. Karel Teige lo había dejado escrito en sus textos teóricos de los años 30': el collage y el fotomontaje pueden ser utilizados como expresión artística o como ilustración de libros, revistas y carteles. Además de teorizar sobre el collage, el surrealismo (y su relación con las pulsiones sexuales), Teige elaboró entre 1935 y 1951 la considerable cifra de 374 collages, que permanecieron ocultos durante tiempo a la mirada del público, como buena parte de los creados por Pep Carrió durante treinta años, guardados todavía en el ámbito privado, incluso íntimo, de carpetas y cuadernos.

Hemos empezado hablando de fotografías encontradas y hemos acabado hablando de eros, también podríamos haber citado a tánatos.

\section{Caso $N^{\circ}$ 3. El fabricante de cabezas}

Pep Carrió dibuja todos los días desde hace años en un pequeño cuaderno al uso. Cada dibujo ocupa una página, excepcionalmente dos, eso da un total de algo más de trescientas imágenes al año, todas ellas tienen para cada año un nexo de relación: un color (azul), una iconografía (vegetal, cabezas), un instrumento de dibujo (rotulador de punta fina), constricciones que el autor respeta escrupulosamente a lo largo del año. Con el paso del tiempo esta serie de cuadernos anuales se ha integrado en un proyecto denominado Diario visual.

El cuaderno de 2015 estuvo consagrado íntegramente al dibujo de cabezas, que ya habían aparecido tímidamente en un cuaderno de 2010. El 31 de diciembre de 2015, Pep Carrió contaba con 365 dibujos originales representando cabezas, 365 obras únicas.
Acerca de los cuadernos de Pep Carrió, de sus procedimientos retóricos (toda constricción es retórica) y poéticos (algunas constricciones pueden ser poéticas) se ha escrito abundantemente en dos catálogos diferentes de la misma exposición (caso excepcional al que remitimos): Abierto todo el día (Valencia, UNIT / La imprenta C.G., 2013) y Pensar con las manos (Valencia, UNIT / La imprenta C.G., 2014).

El cuaderno de 2015 estuvo consagrado íntegramente al dibujo de cabezas, que ya habían aparecido tímidamente en un cuaderno de 2010. El 31 de diciembre de 2015, Pep Carrió contaba con 365 dibujos originales representando cabezas, 365 obras únicas. Anotaremos que un cuaderno íntimo no puede acceder a la categoría de arte hasta hacerse público, y es el caso de los cuadernos que nos ocupan. Anotaremos también que no se trata de bocetos, entendiendo por boceto una imagen previa a otra que tendrá la categoría de definitiva. Todas las imágenes de Diario visual desde 2007 son definitivas.

En este caso $n^{\circ} 3$ indagaremos qué sucede con el cuaderno. En 2015, ocho de esas imágenes de cabezas se estampan mediante serigrafía y se presentan en una carpeta numerada, firmada por el autor y con la justificación de tirada avalada por el Taller de Manolo Gordillo (Madrid). Las cabezas ya son públicas y se presentan como obra de arte. 


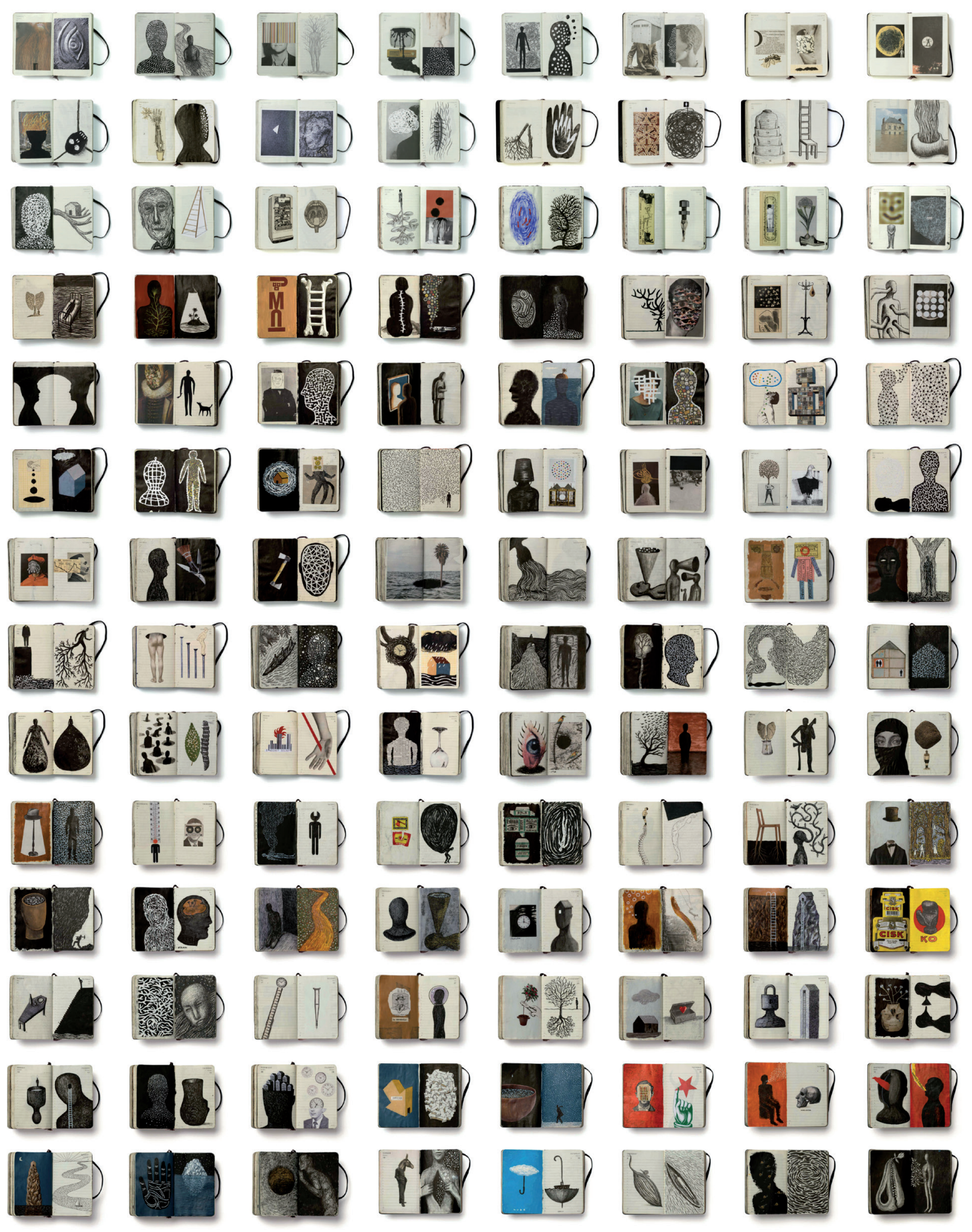

Figura 10.

Diario visual, 2007-2011. 

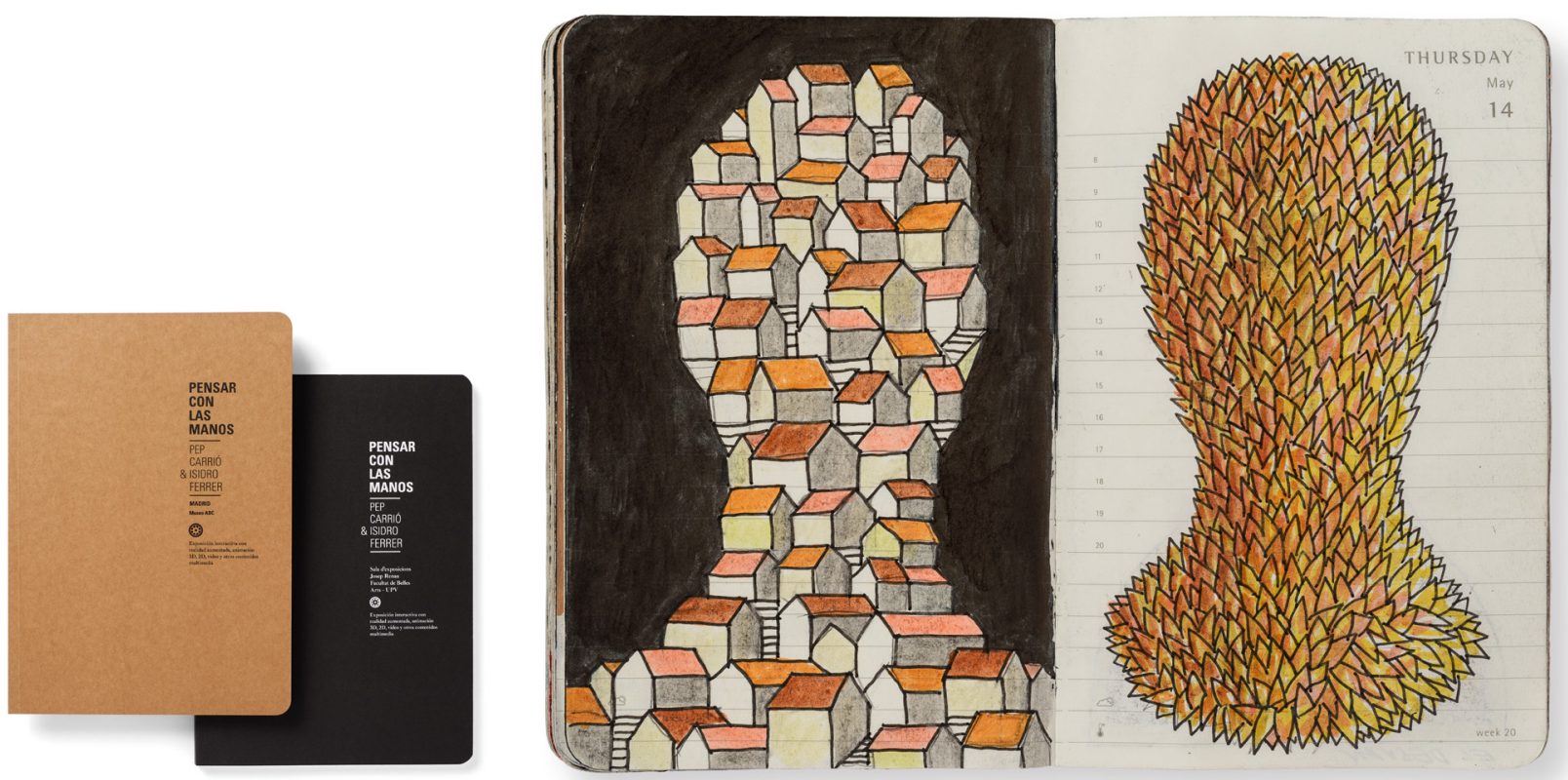

Figura 11.

Catálogo exposición Pensar con las manos, 2014.

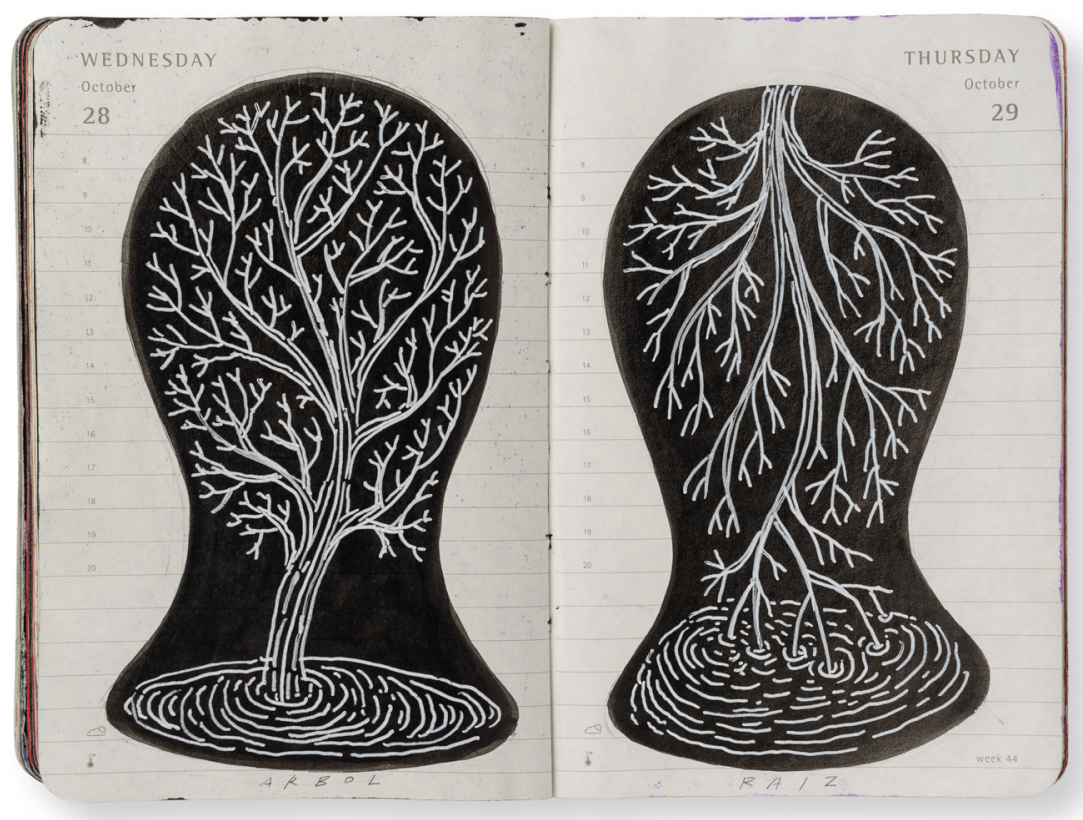

Figura 12.

Diario visual, 2015. 


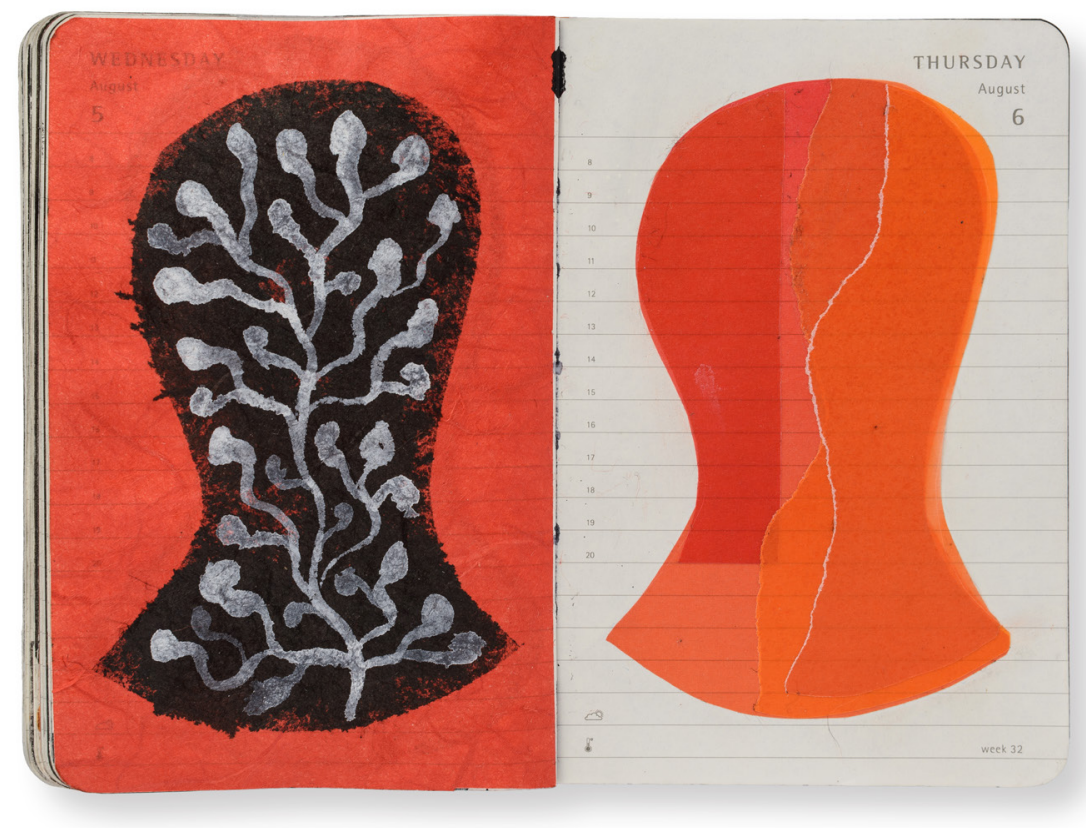

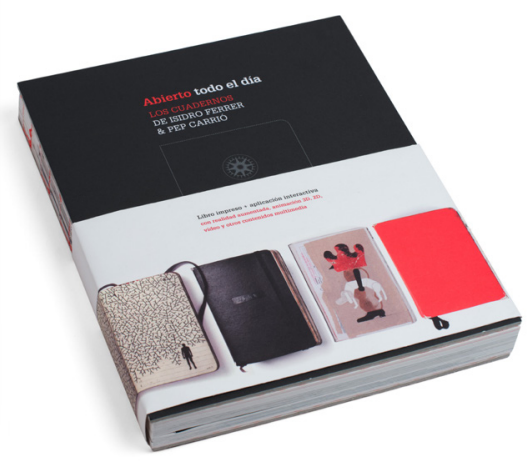

Figura 13.

Libro Abierto todo el día, 2013.

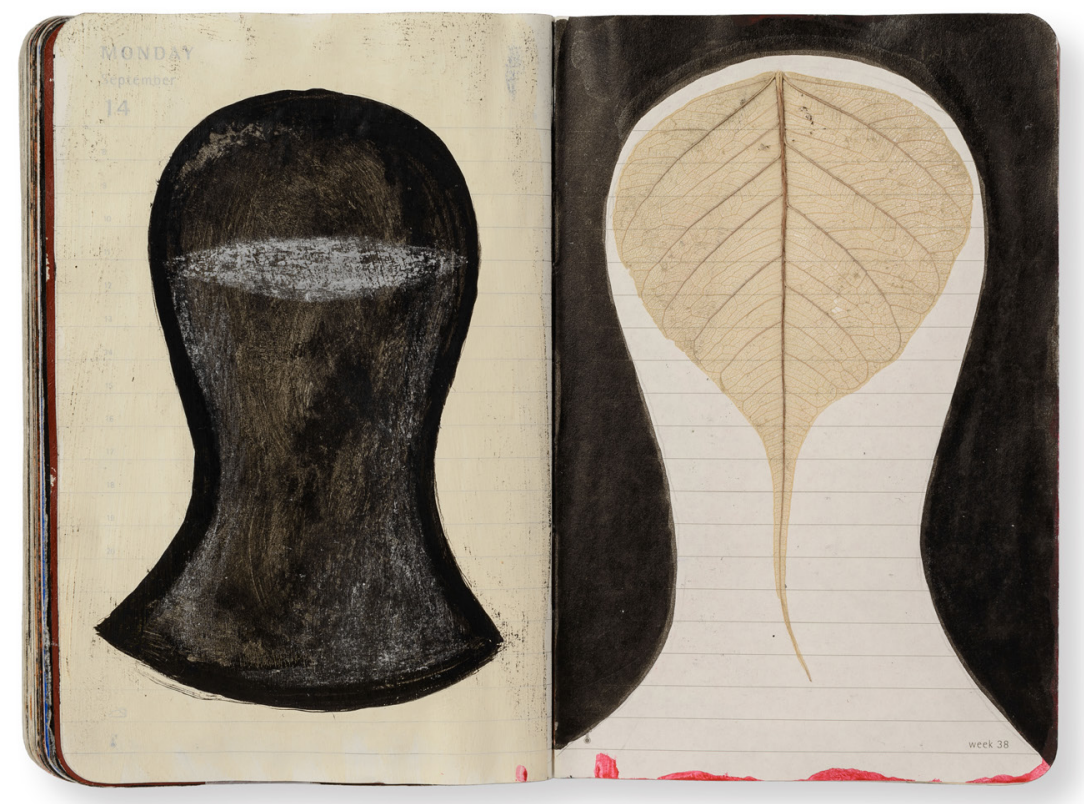

Figura 14.

Diario visual, 2015. 


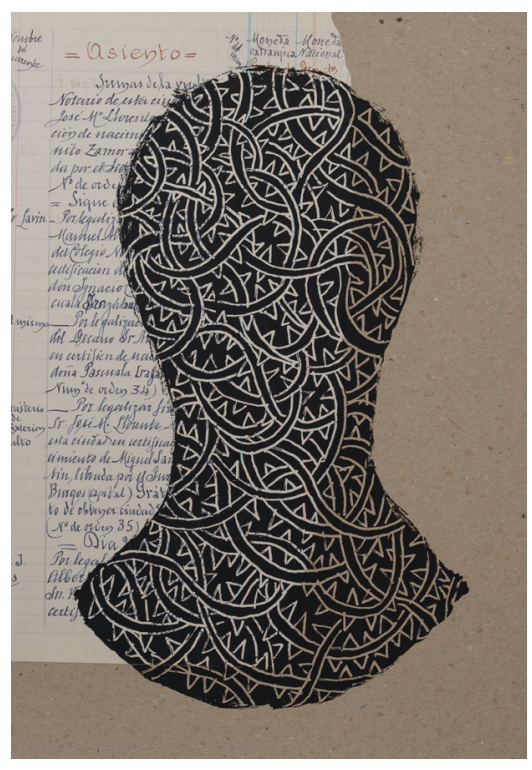

Figura 15.

Carpeta El fabricante de cabezas. Edición de seis serigrafías sobre hojas de un diario de embajada, 2015.
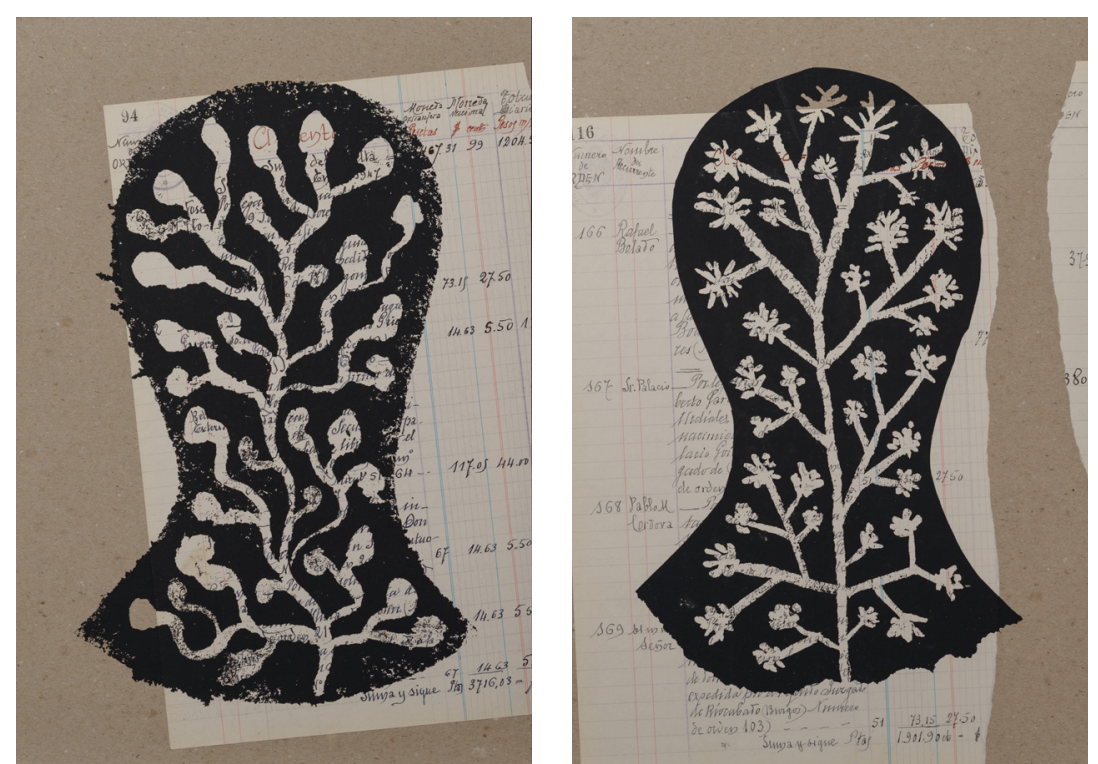

Pep Carrió elige para la estampación de esta serie las hojas de un diario de embajada encontradas en el Rastro. El hecho de que la imagen de cada cabeza se serigrafíe sobre un documento original reducido a la categoría de imagen, convierte a cada una de las piezas en un collage. No solo ha habido una deriva del cuaderno inicial a la carpeta de serigrafías, ha habido también una deriva del dibujo al collage; conviven dos obras que comparten motivo, la cabeza, y se distancian en la poética.

La siguiente decisión que toma Pep Carrió es pasar a volumen algunas de estas imágenes, trasladarlas de la segunda a la tercera dimensión. Como las imágenes de partida, las del cuaderno, no son bocetos, no podemos hablar de un proceso de creación al uso, de aquellos que van del apunte a la obra definitiva, sino más bien de una recreación de la propia obra.

El material utilizado para la construcción de estas cabezas, que podemos llamar esculturas, fue la madera; el uso de la madera, la elección de la cabeza como base, y la opción del collage y del ensamblaje entre objetos nos recuerdan Kopf, la pieza que creó Raoul Hausmann en 1919. Casi cien años separarán aquella cabeza de estas cabezas, un siglo que ha permitido que cualquier objeto cotidiano, por insignificante que sea en su realidad funcional, pueda integrarse en una obra de arte. Si ahora estamos habituados a semejante desplazamiento de sentido, no podemos olvidar que se trata de un cambio profundo en nuestra percepción de la realidad, cambio al que contribuyeron de manera decisiva el dadaísmo y el primer surrealismo.

Estas cabezas, autónomas del cuaderno inicial y de la posterior obra gráfica se expusieron en 2016 en la Galería Blanca Berlín y en el Centro Cultural Conde Duque, en Madrid. En poco menos de un año lo que era un cuaderno íntimo derivó, primero, en una colección de serigrafías de las que podía disfrutar en privado un limitado grupo de compradores, y después volvió a derivar en dos exposiciones abiertas al público en general, en un espacio privado y otro público. La relación autor-obra-público se ve así modificada en cada evolución. 


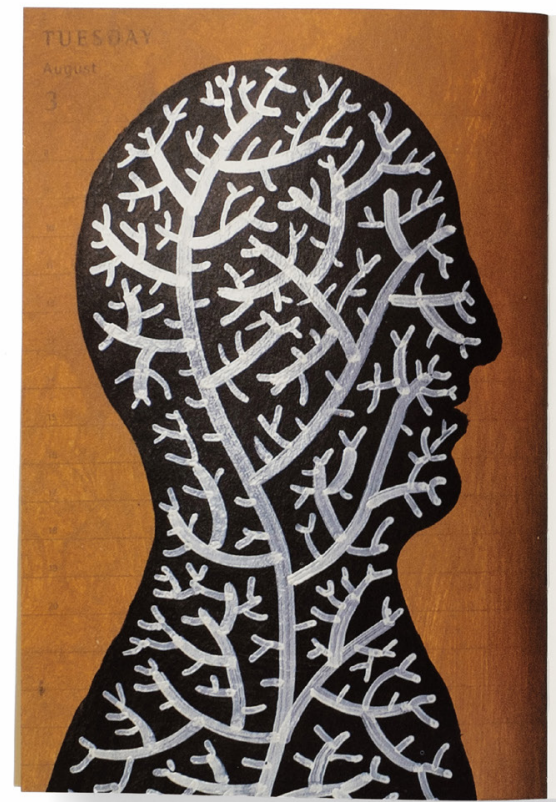

lo primero fueron los pájaros
eso lo sabe hasta un niño de kinder

los pájaros ya estaban ahi

cuando apareció la primera rayita

de cielo azul

y luego la segunda rayita

y luego todo el cielo azul.

después de los pajaros y el cielo

nació la canción melódica

canción pop, si prefieren

lo último en fabricarse

ya lo han adivinado

fueron las cabezas

que miran hacia arriba

y sonrien

inevitables en el paisaje

puro play
Figura 16.

Libro El fabricante de cabezas. \{in pectore\}, 2016.
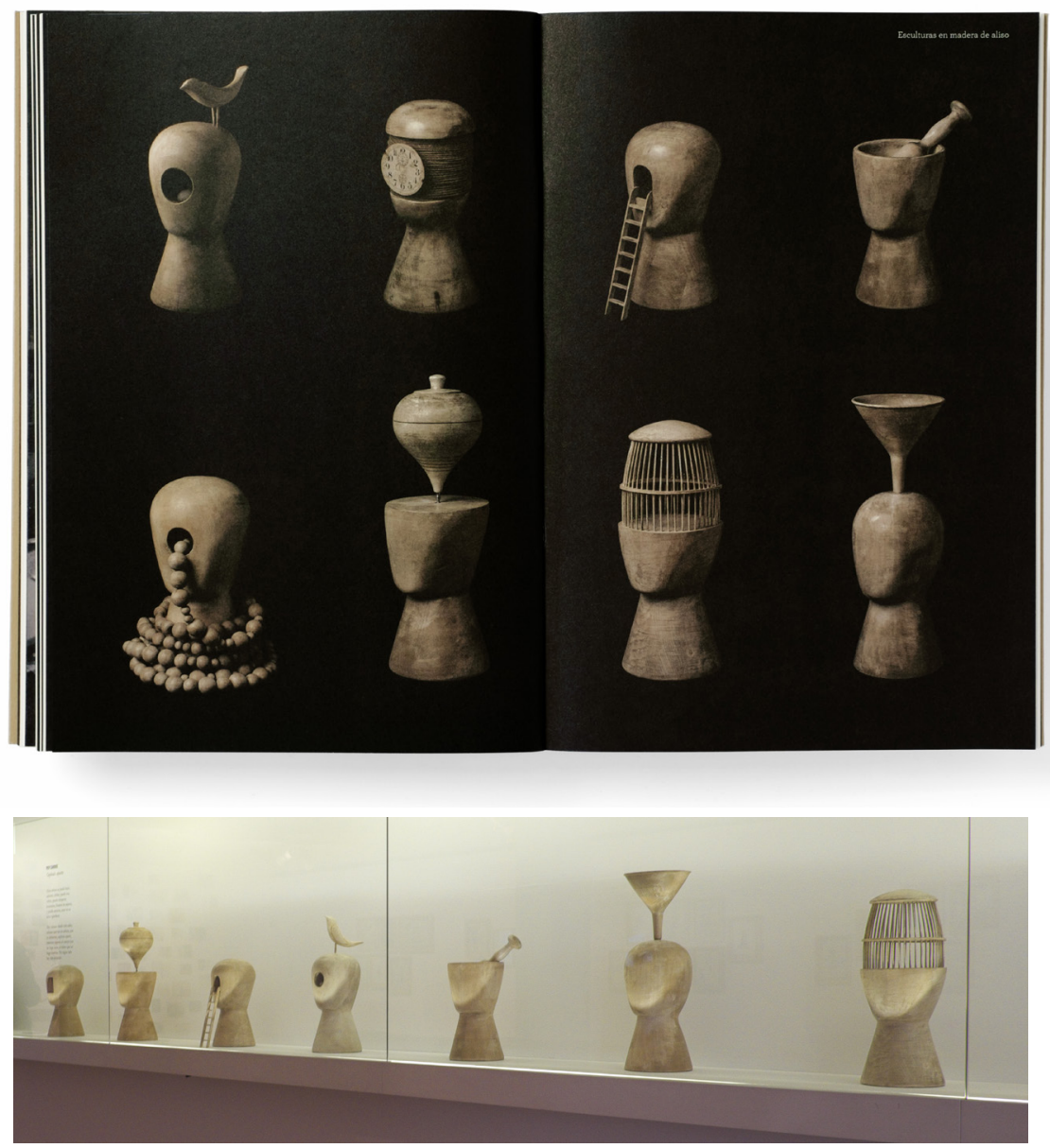

Figura 17

Libro El fabricante de cabezas. \{in pectore\}, 2016.

Fig. 18.

Exposición Pensar con las manos. Museo ABC. 2014. 

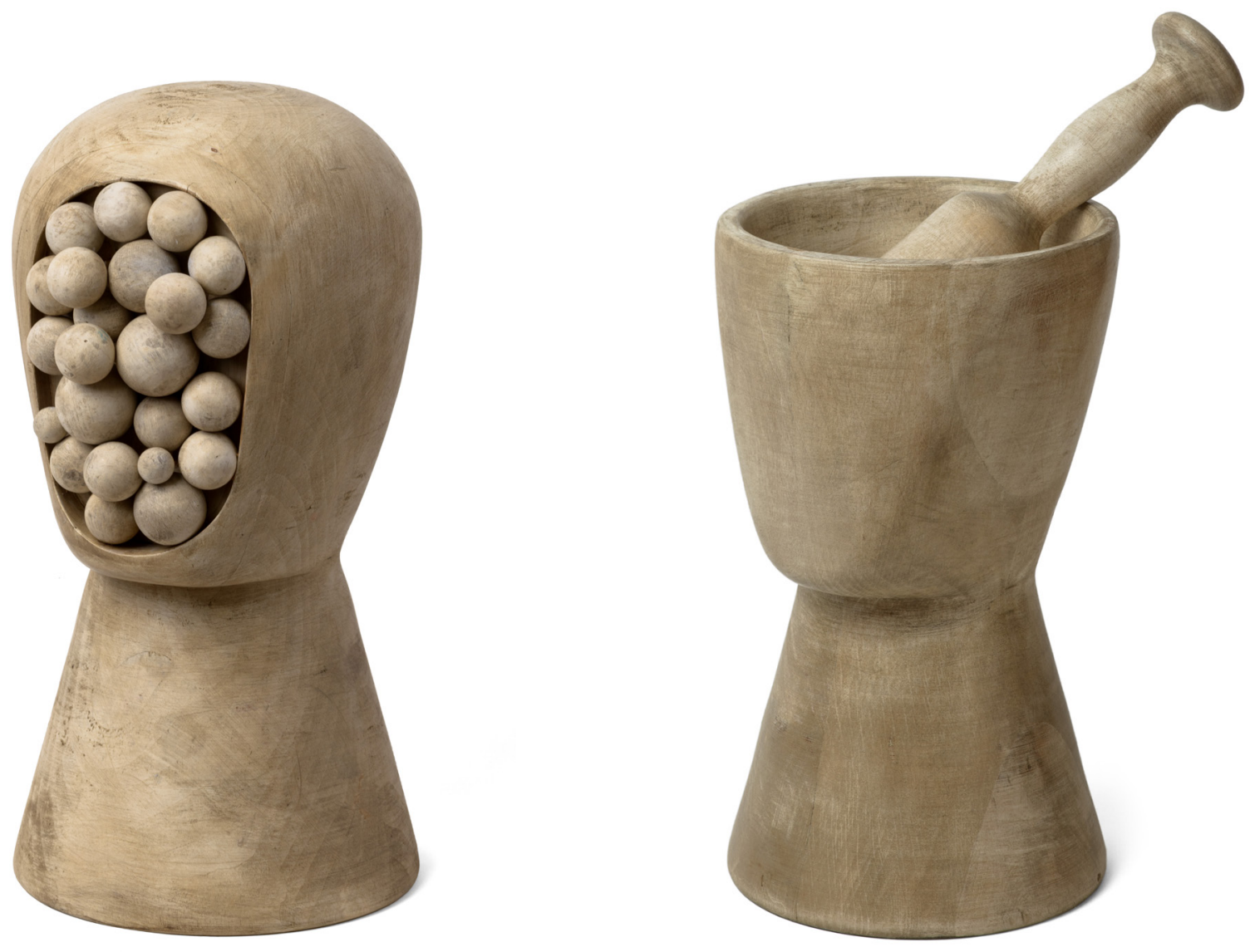

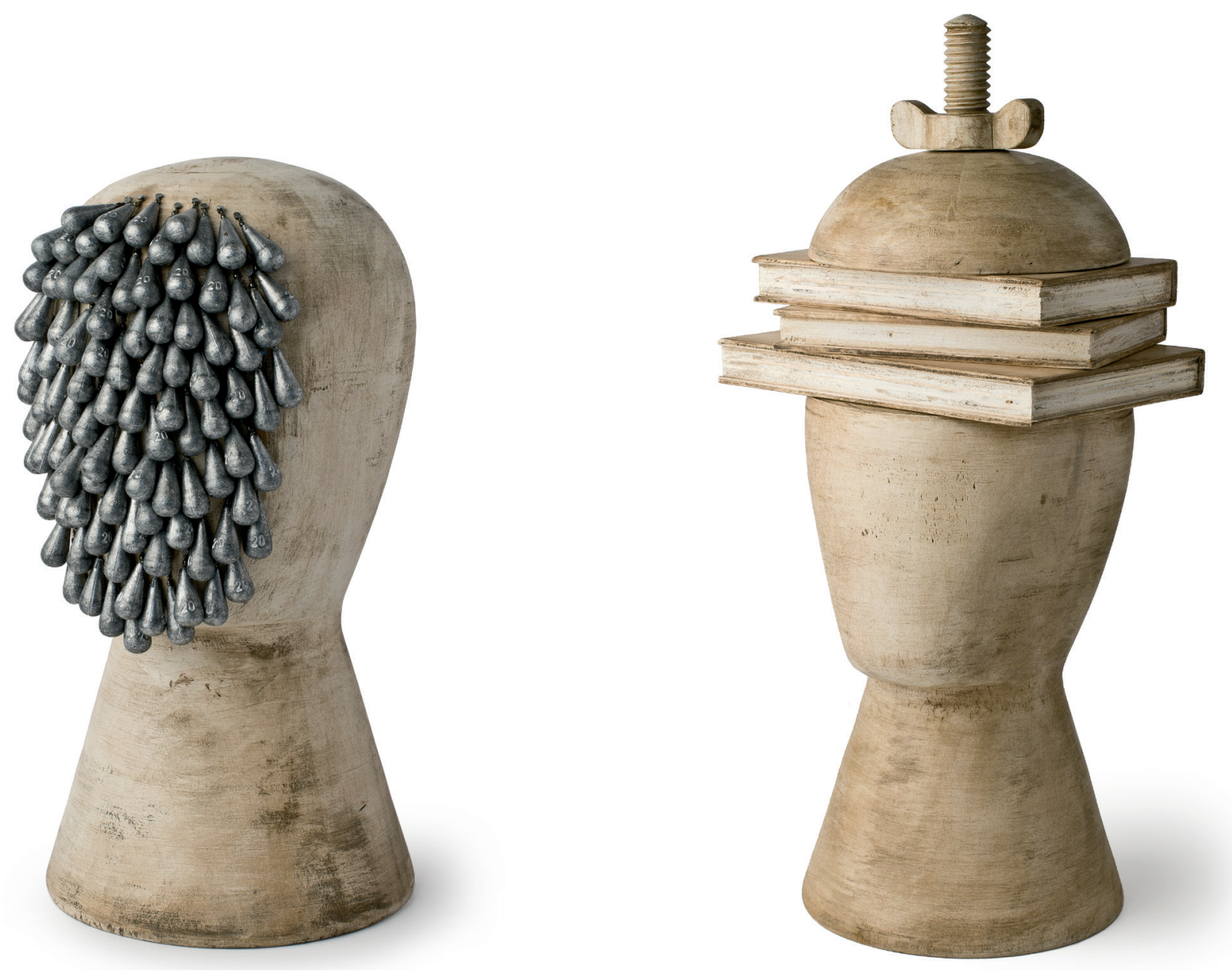

Figura 19.

Exposición El fabricante de cabezas.

Esculturas en madera de aliso realizadas en el taller de Francisco Martín,

maestro tornero, 2016. 
Aún hay otra aparición de las cabezas, será ese mismo 2016. La editorial \{in pectore\} publica un libro singular (la denominación es de Pep Carrió) que, por un lado, actúa como archivo documental de las tres apariciones precedentes (cuaderno, carpeta, esculturas), y por otro lado es un libro de poesía con textos originales escritos para la ocasión por un autor profesional.

Pep Carrió es editor, \{in pectore\} fue creada por él en 2012, el hombre que diseñó gráficamente y sigue diseñando cientos, miles de libros (es su principal ocupación), decidió crear su propia editorial. \{in pectore\} es uno de los tantos proyectos que Carrió ha puesto en marcha en su vida movido por dos intereses: desarrollar y coordinar proyectos en colaboración y unir su producción al texto, generalmente literario.

Respecto al primer interés, podemos seguir el hilo desde las primeras publicaciones colectivas: Bangladesh. La cocina de hoy de siempre (1994), Bar adentro (1997), Abrecartas (2001), hasta la reciente exposición Des/Cubiertas (DIMAD, Círculo de Bellas Artes, 2020). Solo en esos cuatro proyectos descubrimos decenas de nombres ligados a la ilustración y el diseño gráfico desde la Transición hasta nuestros días.

De la parte literaria de los proyectos de Carrió se han ocupado Fernando Beltrán, María José Ferrada, Menchu Gutiérrez y Grassa Toro. Salvo en los cuadernos íntimos, exentos de texto, es difícil encontrar obra de Pep Carrió que no esté ligada a la palabra. En el diseño de libros de otros, en la creación de los propios, en los catálogos de sus exposiciones, en las invitaciones a las mismas, en las cajas de artista a las que nos hemos referido anteriormente, incluso en sus inveteradas felicitaciones de año nuevo, que envía regularmente por correo postal, siempre está presente la palabra.

Hemos empezado hablando de cabezas dibujadas y hemos acabado hablando de gente que se junta para crear.

\section{Caso No 4. La biblioteca de Vargas}

Carrió ha llevado

al límite de las

posibilidades el alejamiento de la figura del diseñador autor, quien necesite una prueba de la afirmación que acabamos de hacer puede comparar con calma la serie de cubiertas que proponemos.
Hay mucha gente que se llama Vargas, algunas personas se llaman Mario Vargas, casi nadie se llama Mario Vargas Llosa.

Cuando Pep Carrió recibió el encargo de la editorial Alfaguara para crear el diseño gráfico de la Biblioteca Mario Vargas Llosa, llevaba algunos años realizando cubiertas para Taurus y, analizando su producción, empezaba a intuirse que había renunciado al diseño de autor. Entendemos por diseño de autor el que, independientemente del objeto diseñado, nos permite identificar siempre (con escaso margen de error) al diseñador que lo ha creado. Lo contrario del diseño de autor no es diseño anónimo, quizás no tenga nombre, pero podemos describirlo como aquel que se adecua a cada encargo y cambia sus propuestas formales y semánticas en función de las características del objeto, hasta volver imposible saber quién está detrás de cada creación.

Carrió ha llevado al límite de las posibilidades el alejamiento de la figura del diseñador autor, quien necesite una prueba de la afirmación que acabamos de hacer puede comparar con calma la serie de cubiertas que proponemos. 

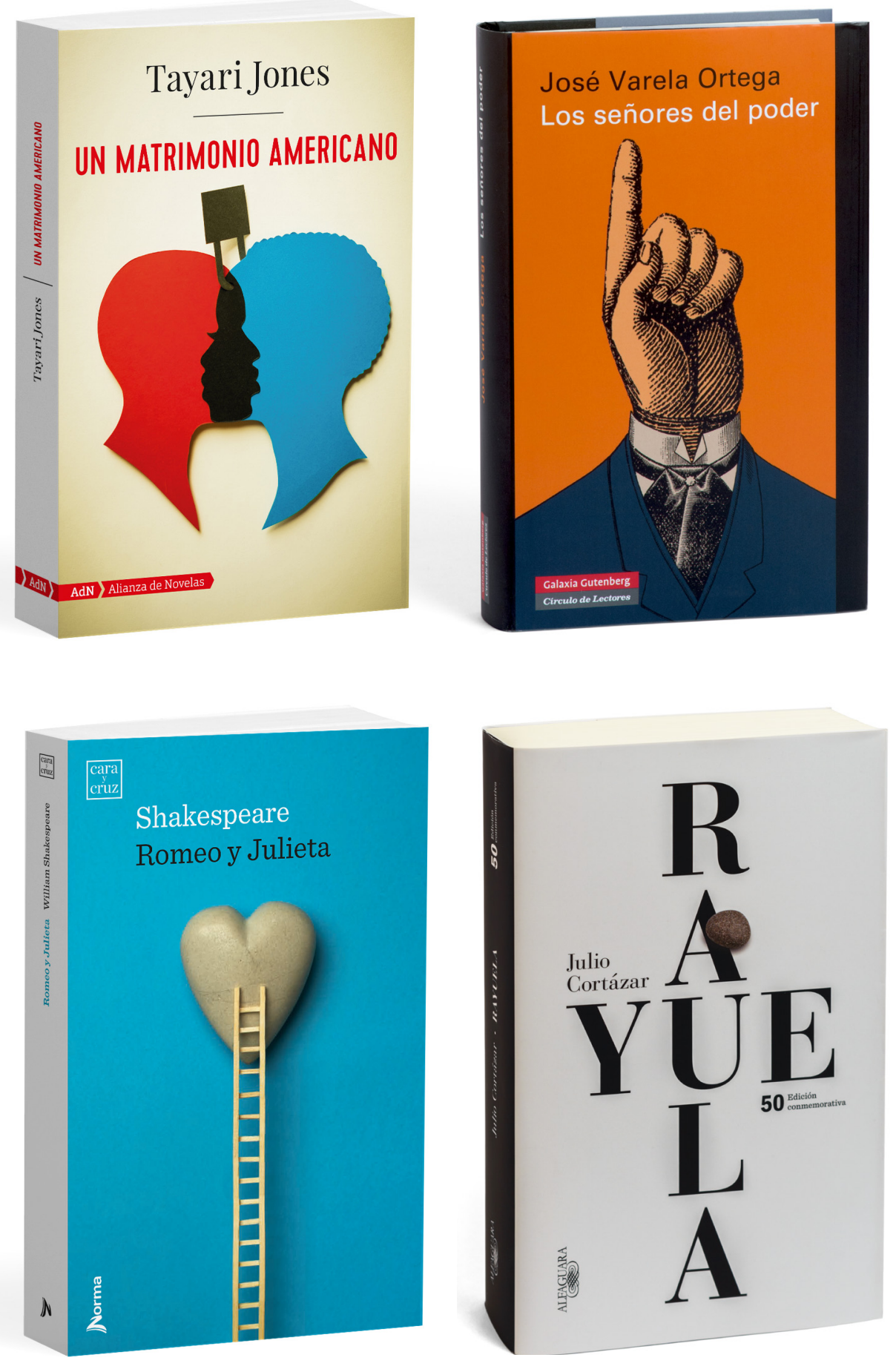

Figura 20.

Cubiertas para las editoriales AdN, Galaxia Gutenberg, Norma y Alfaguara. 


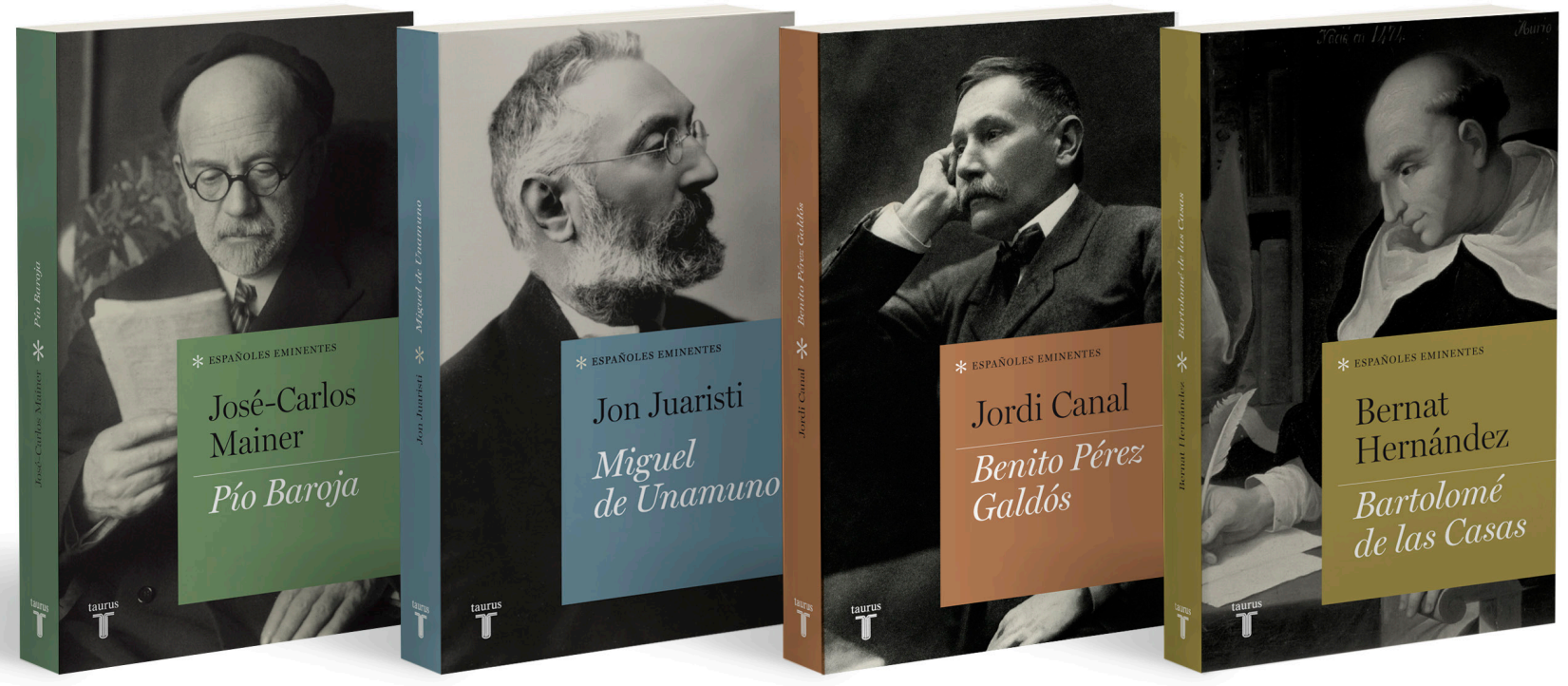

Figura 21.

Cubiertas para la editorial Taurus.
Repasemos algunos datos significativos del encargo de nuestro caso $n^{0} 4$. Las colecciones de libros, tan habituales hasta hace veinte años en la venta a través de club de lectura o en librería, se empezaban a ver relegadas a la venta en kiosco de prensa y a funcionar de manera autónoma al catálogo de cualquier editorial. No era el caso, Biblioteca Mario Vargas Llosa estaba destinada a venderse en librería, coincidiendo en mesas y estantes con el resto de catálogo de Alfaguara.

La relevancia del autor y de las obras permitía suponer una distribución y venta masiva, lo que confería a la edición un carácter popular, en el mejor sentido de la palabra.

Independientemente de la variedad de registros literarios de Vargas Llosa, en el imaginario de lectores de finales del siglo XX está presente su especial manera de entender el realismo, fruto de un choque entre la organización social y el mundo de lo irracional.

A esta poética responde la selección de imágenes (una serie) que hace Pep Carrió y que deriva hasta la cubierta del libro desde sus respectivos originales concebidos como piezas únicas de artista, algunos de ellos expuestos anteriormente en galerías de arte. Entrega tras entrega, veremos aparecer objetos, que no costaría calificar como surrealistas, collages, ensamblajes, piezas ancladas en lo social (objetos cotidianos, fotografías familiares, etc.) y decididamente irracionales.

Podría pensarse que esta adecuación entre imagen e imaginario es suficiente para asegurar el éxito del diseño de la colección. Una cubierta es mucho más que una imagen, por mucho que se identifique plenamente con la obra que presenta; una cubierta es un complejo espacio de información (parecido al cartel) en el que conviven otros elementos; acerca de cada uno de ellos tendrá que tomar decisiones el diseñador. 
La casa verde

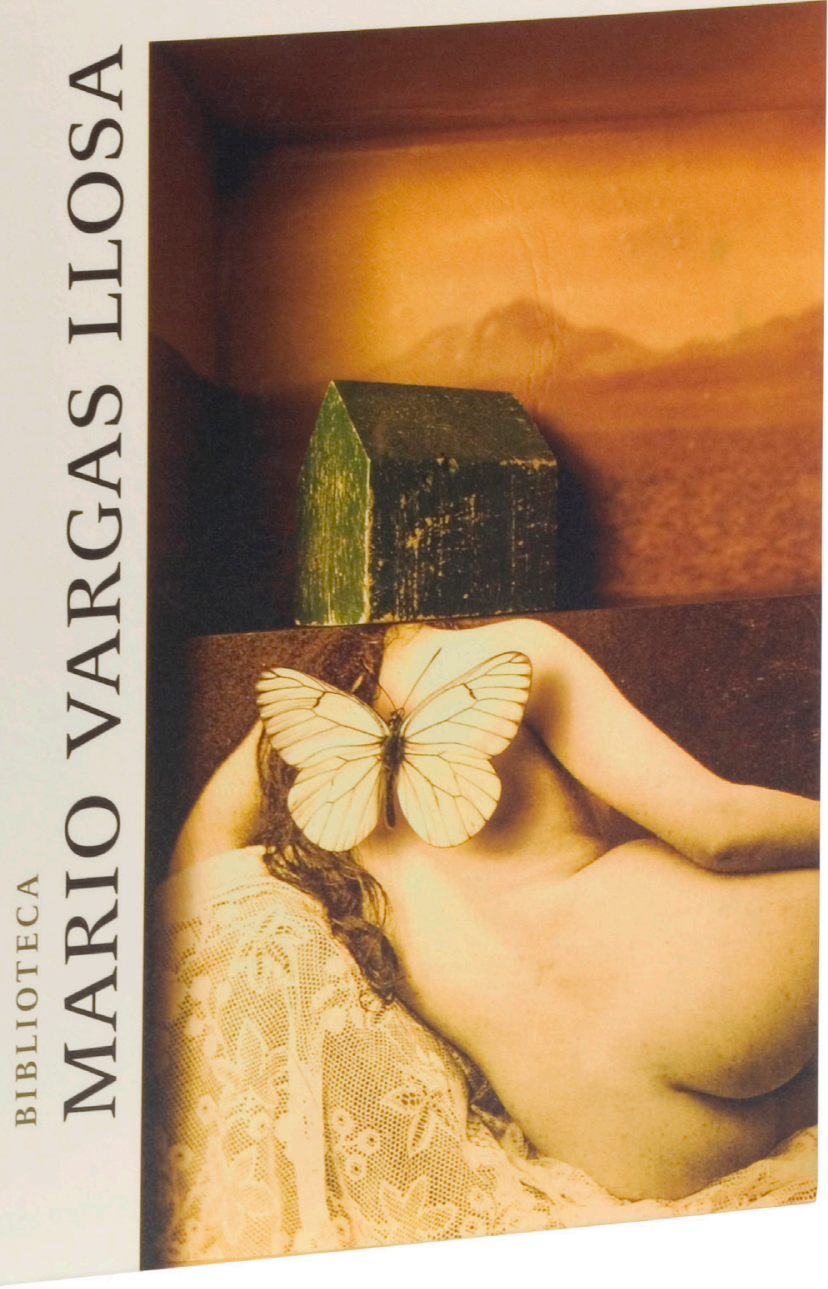

Figura 22.

Biblioteca Mario Vargas Llosa. Alfaguara. 2004. 

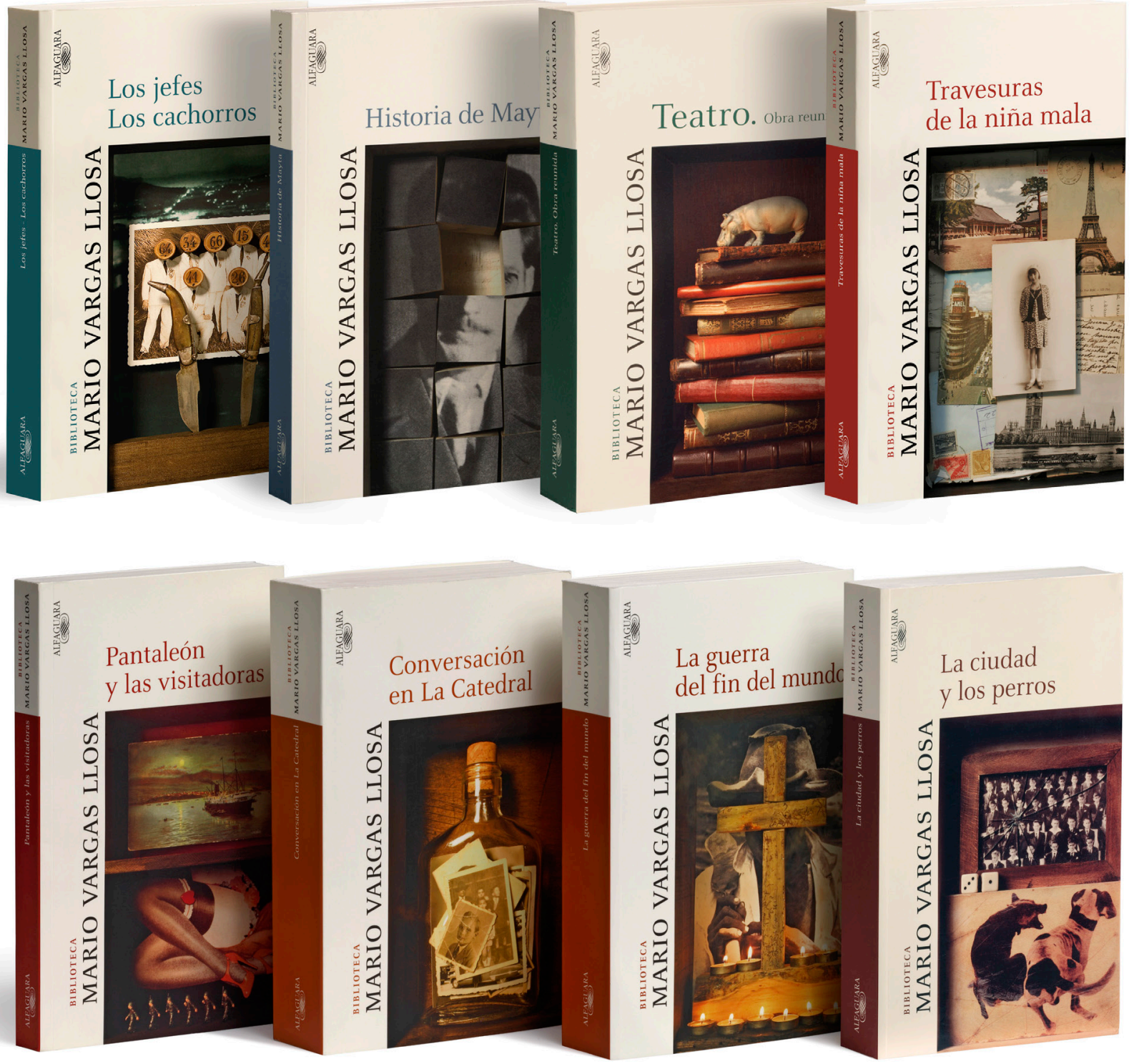

Figura 23.

Biblioteca Mario Vargas Llosa.

Alfaguara, 2004. 
Los cinco elementos de cubierta de Biblioteca Mario Vargas Llosa tienen una significación vistos aisladamente y en relación con los otros, incluso con elementos ausentes. Sigamos las pistas.

Fondo. Las cubiertas de Alfaguara se reconocen por tener el fondo negro (no son las únicas en el panorama editorial español). Cambiar radicalmente al color crema, cercano al blanco, es una decisión arriesgada en lo comercial (se pierde la identificación directa) y perfectamente argumentada en lo editorial: estamos ante una colección excepcional que tiene que convivir con el amplío catálogo de Alfaguara y, al tiempo, diferenciarse del resto de volúmenes.

Logotipo. Obligado. Encuentra su espacio en un vértice que no interfiere la lectura del resto de la cubierta.

Título de colección. Mayor en cuerpo que el título de la obra, colocado en vertical, a la izquierda, crea su propio espacio autónomo, casi como si el lomo se hubiera desplazado a la derecha, y permite otorgar a la colección una relevancia sin necesidad de imponerse jerárquicamente a los dos últimos elementos de los que nos ocuparemos: el título y la imagen, que juntos recrean una cubierta dentro de la cubierta.

Título de la obra. De factura y colocación clásica. Varía de color coincidiendo con las variaciones de color en la mancha del lomo (es una serie). La tipografía utilizada (Celeste) para los dos títulos formaría parte de las tipografías que Pierre Faucheux consideraba como elegantes, capaces de expresar elegancia. Que una tipografía sea capaz de expresar es una evidencia que no debería confundirse con lo que algunos autores denominan tipografías expresivas, escasamente utilizadas por Carrió, que suele decantarse por tipos "clásicos», independientemente de que su invención date de siglos o de meses.

Imagen. No volveremos sobre el análisis iconográfico; lo excepcional desde el punto de vista del diseño gráfico es que la imagen no aparece nunca manchada por ninguno de los textos con los que convive, algo poco común en el diseño editorial. Esa autonomía visual nos permite verla como una obra con significación propia, sin detrimento de su aportación a la significación global de la cubierta. Es como si alguien hubiera acabado de leer, cerrado las páginas y depositado una postal sobre un libro de un tal Vargas.

Diseñar es un oficio artesanal, uno de los fundamentos de la artesanía es partir de objetos ya existentes y buscar las posibilidades de mejora; el concepto de mejora, que lleva implícito el de innovación, es amplio, probablemente ilimitado. Desde este principio creó Pep Carrió Biblioteca Mario Vargas Llosa.

Antes de cerrar el caso, queremos convocar la opinión de un experto, escribe Massin en L'ABC du métier (Paris, Imprimerie Nationale, 1988): "Una cubierta no puede decir todo; es incapaz de contar una historia; como mucho puede captar un instante significativo o proponer una alegoría. No puede jugar el papel de un sumario o de una tabla de materias. Debe limitarse a sugerir, a plantear un problema. No le está prohibido intrigar, es decir crear un misterio".

Cuando Massin pide que la cubierta plantee un problema, podemos entender que está pidiendo que obligue a los lectores a buscar una respuesta, que les obligue a pensar.

Hemos empezado hablando de un tal Vargas y hemos acabado hablando de Daniel Gil.

\author{
Que una tipografía sea \\ capaz de expresar es \\ una evidencia que no \\ debería confundirse con \\ lo que algunos autores \\ denominan tipografías \\ expresivas, escasamente \\ utilizadas por Carrió.
}




\section{Caso $N^{\circ}$ 5: Leer entre imágenes}

Si en cualquier investigación que quiera tener éxito, es recomendable leer entre líneas, en el caso que nos ocupa aconsejamos leer entre imágenes: Pep Carrió diseña libros y hay que acercarse a ellos para descubrir la amplia diversidad de respuestas, de soluciones. ¿Dónde encontrarlos? Como la cantidad de volúmenes diseñados se cuenta por miles, es muy posible que usted ya haya tenido alguno entre sus manos. Si no ha sido así, le recomendamos que siga, una vez más, las pistas.
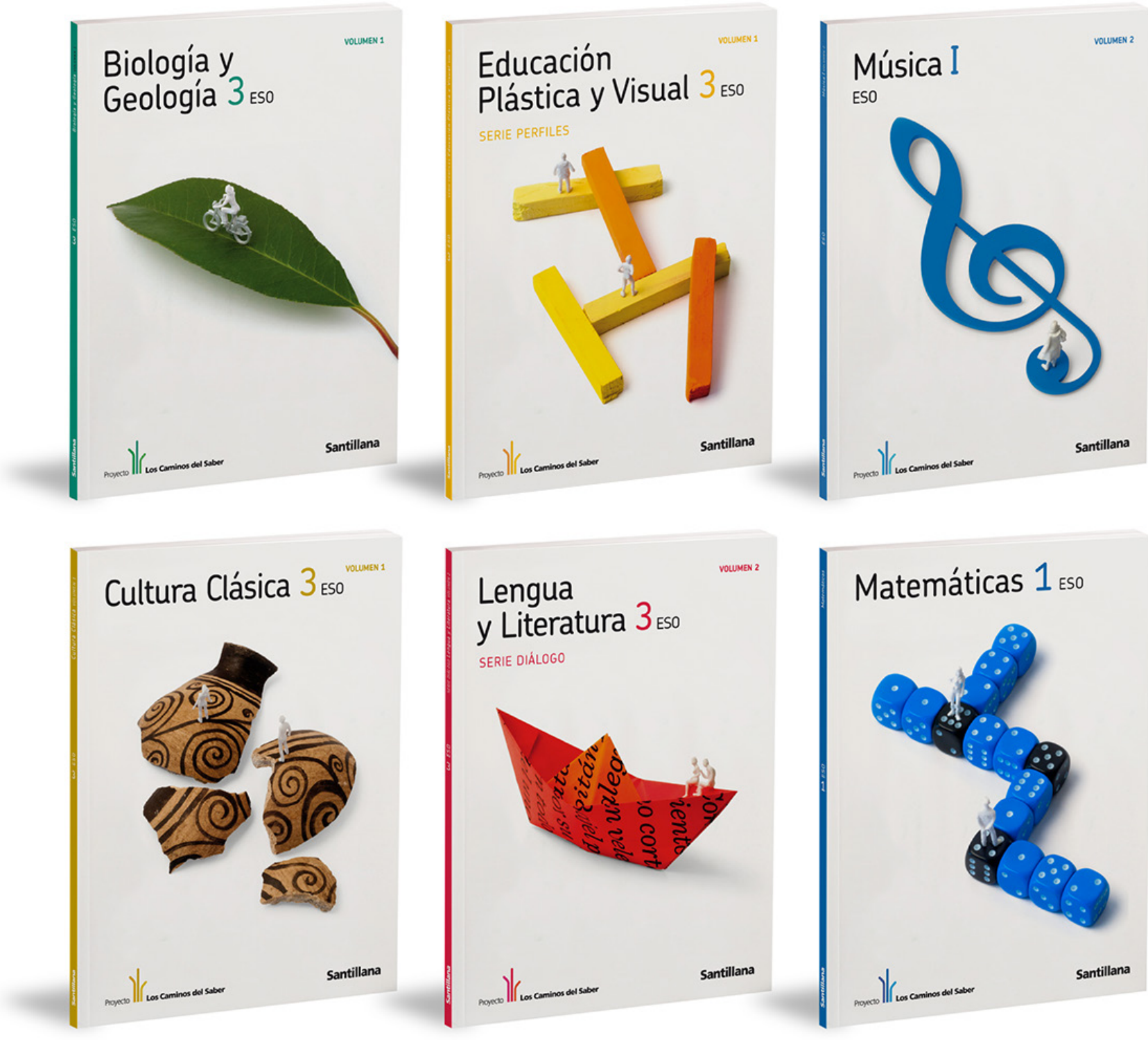

Figura 24.

Proyecto Los Caminos del Saber, Santillana Educación, 2011 
Libros diseñados en todo o en parte por Pep Carrió hay en editoriales españolas y latinoamericanas de gran tirada (Alfaguara, Taurus, Norma, Galaxia Gutemberg...), en publicaciones institucionales (RAE, Banco de España, BNE...), en autoediciones: (30 de diciembre, Al otro lado de la línea...), y en libros de texto (Santillana, Richmond...).

Pep Carrió lleva casi veinte años diseñando libros de texto y creando la identidad visual de grandes proyectos educativos (Saber Hacer, Santillana Compartir, loqueleo...)

El diseño gráfico y la ilustración del libro de texto es una pista que raramente se sigue en la investigación. Sería difícil acertar con la razón de este desprecio, acaso se considere un espacio de comunicación «menor»; sin embargo, es determinante en la educación estética de la mayoría de la población que convive con estos libros durante muchas horas de muchos días de muchos años, a lo largo de la etapa más permeable a la educación del gusto: la infancia y la adolescencia.

En un sector que no admite demasiadas experimentaciones gráficas, el aporte cuantitativo y cualitativo de Pep Carrió ha sido relevante y, en ocasiones, ha abierto caminos que han secundado otros actores. Vuelve a repetirse la estrategia de creación: cualquier recurso, de su autoría o de autor invitado, puede encontrar espacio en las cubiertas de matemáticas o historia: ilustración, collage, objeto, figuración en 3D, fotografía. Y otra vez Carrió convoca en torno a estos proyectos a una extensa nómina de colaboradores. Leer los créditos de la $2^{\mathrm{a}} \mathrm{O}$ la $3^{\text {a }}$ de cubiertas de estos libros escolares nos permite tener una amplía visión de la ilustración española de los últimos veinte años.

Quizás sea esta identificación entre diseñador y libro lo que ha propiciado que también se requiera del oficio de Pep Carrió en encargos relacionados con el contexto de la lectura, ya sea en campañas de identidad visual para eventos y programas, ya sea como identidad visual de empresas relacionadas con el sector, ya sea para reconocer a profesionales relacionados con el libro, reconocimientos que toman forma de pequeña escultura y que, sumados, ya empiezan a conformar un pequeño jardín de las delicias lectoras.

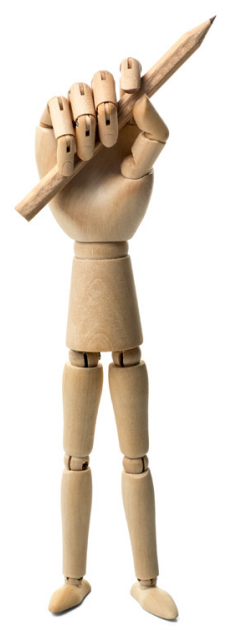

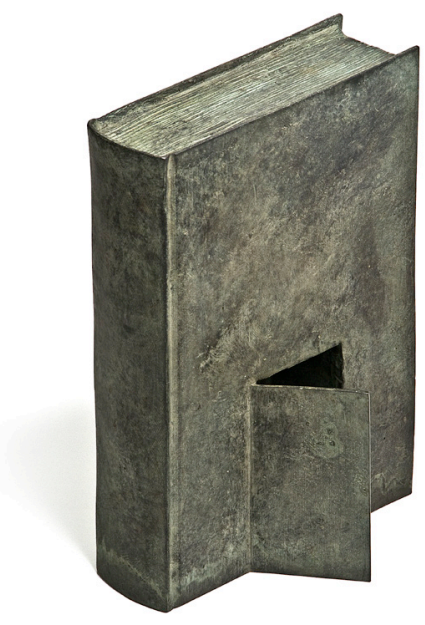

Figura 25.

Premio Apim, 2019.

Figura 26.

Premio Leyenda, 2008.

Figura 27.

Premio Aula de las Metáforas, 2009.

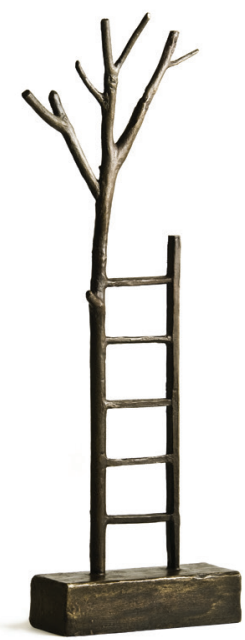




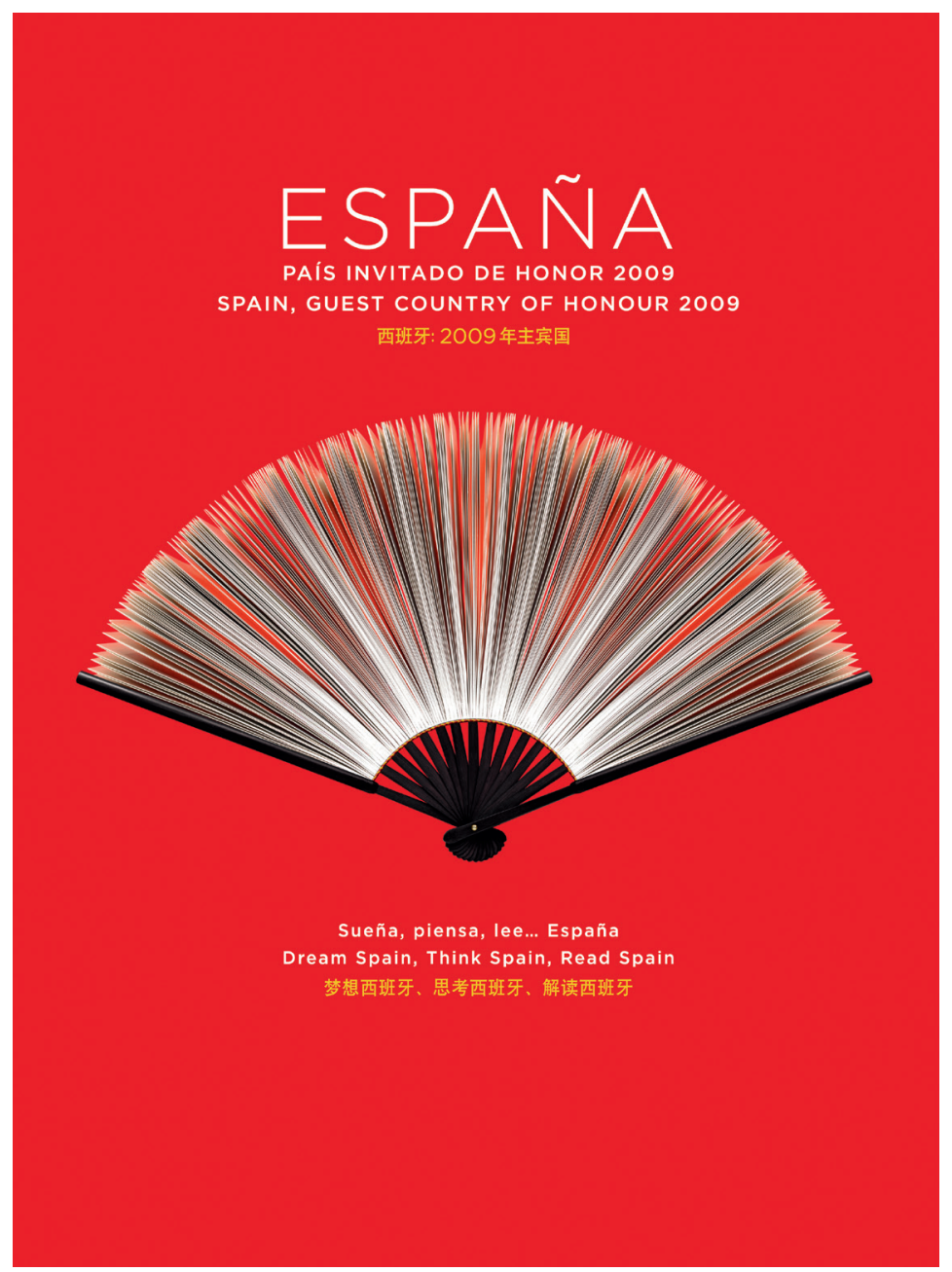

Figura 28.

España país invitado. Feria del libro de Pekin. Ministerio de Cultura, 2004

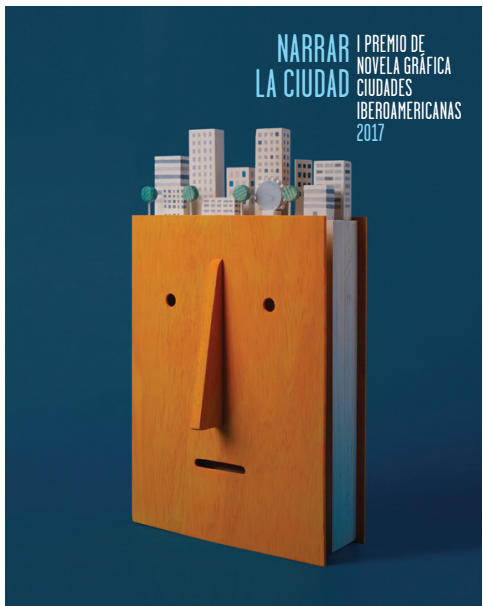

Figura 29.

Premio Narrar la ciudad. UCCI, 2017

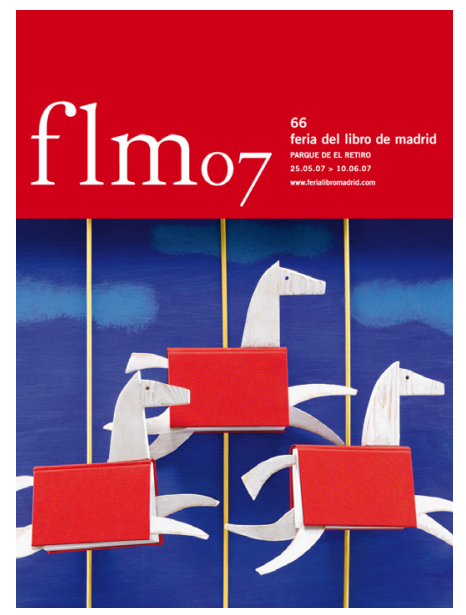

Figura 30.

Feria del libro de Madrid, 2007
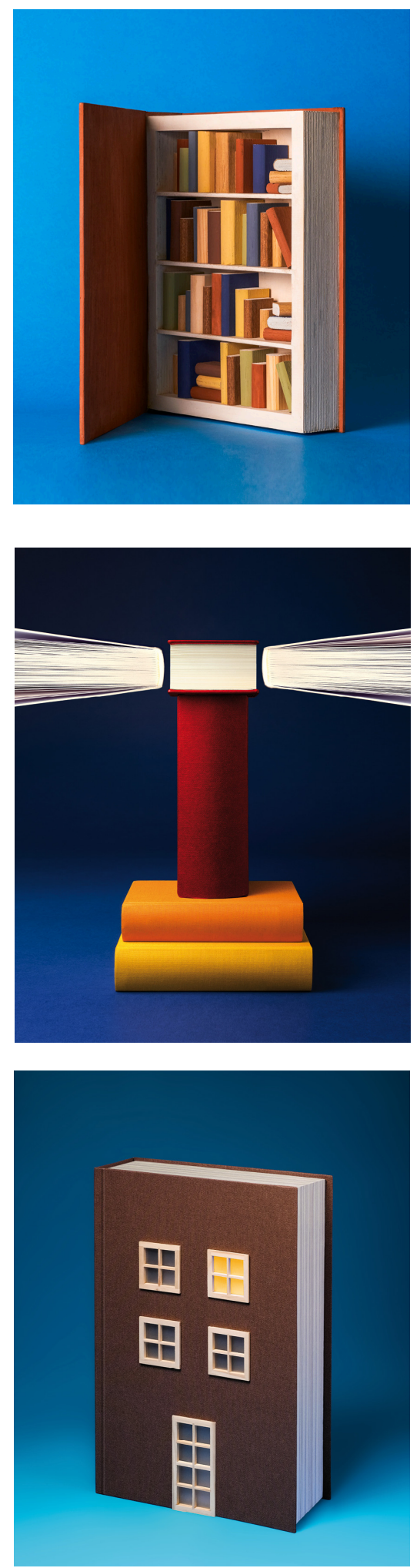

Figura 31.

Biblioteca Palermo, 2014-2021 

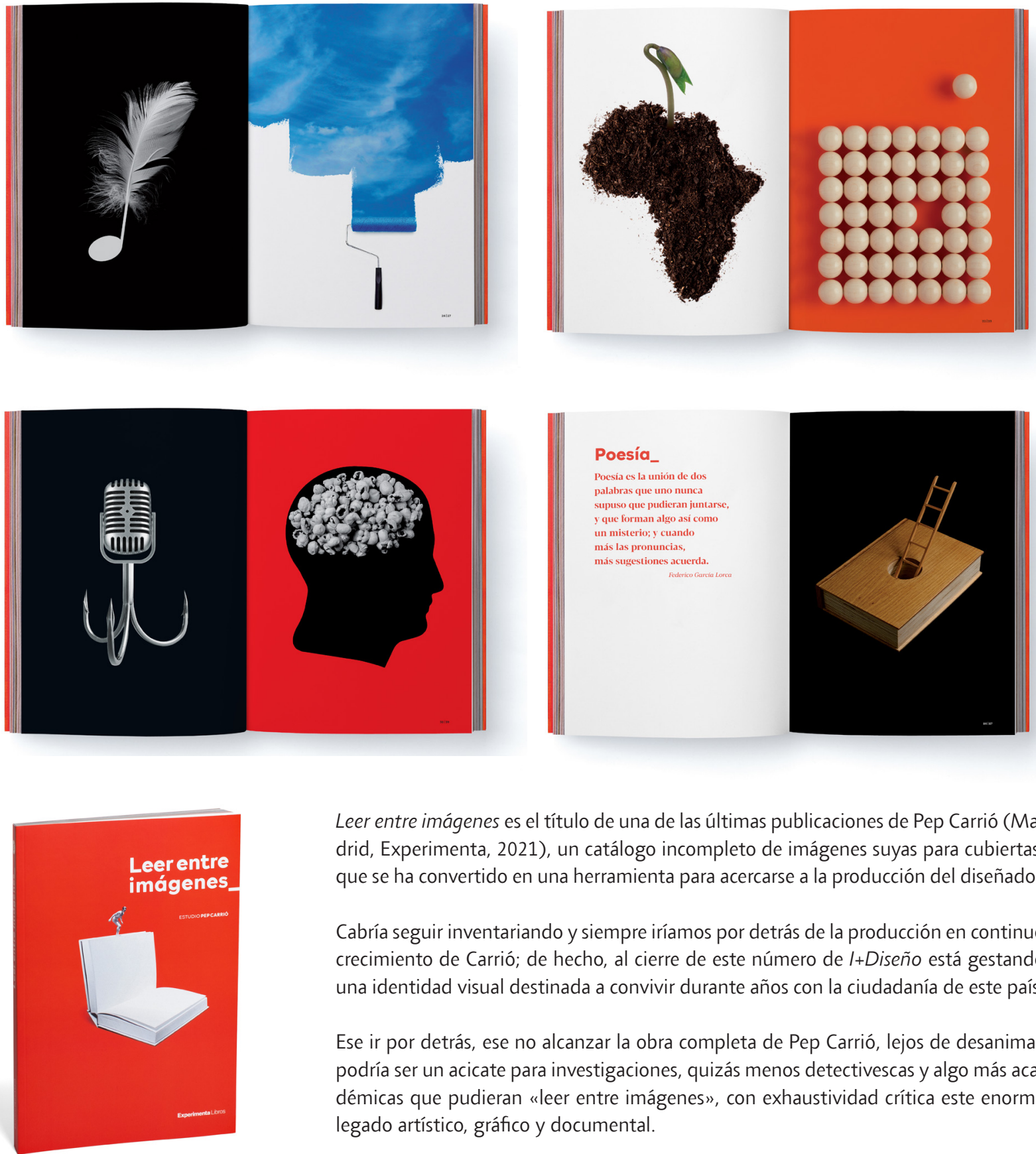

Leer entre imágenes es el título de una de las últimas publicaciones de Pep Carrió (Madrid, Experimenta, 2021), un catálogo incompleto de imágenes suyas para cubiertas, que se ha convertido en una herramienta para acercarse a la producción del diseñador.

Cabría seguir inventariando y siempre iríamos por detrás de la producción en continuo crecimiento de Carrió; de hecho, al cierre de este número de I+Diseño está gestando una identidad visual destinada a convivir durante años con la ciudadanía de este país.

Ese ir por detrás, ese no alcanzar la obra completa de Pep Carrió, lejos de desanimar, podría ser un acicate para investigaciones, quizás menos detectivescas y algo más académicas que pudieran «leer entre imágenes», con exhaustividad crítica este enorme legado artístico, gráfico y documental.

La imagen del estudio de diseño gráfico de Pep Carrió es una colección de semillas reco-

Figura 32 .

Libro Leer entre imágenes. gidas por todo el mundo. Colección y semillas: no puede quedar más claro.

Experimenta. Madrid, 2021.
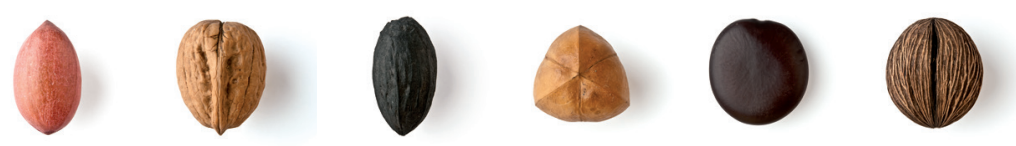